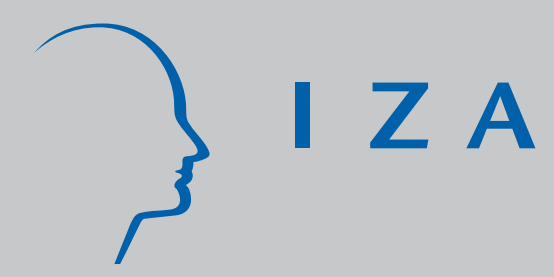

IZA DP No. 2291

Life Cycle Effects of J ob Displacement in Brazil

J asper Hoek

September 2006 


\title{
Life Cycle Effects of Job Displacement in Brazil
}

\author{
Jasper Hoek \\ U.S. Department of the Treasury \\ and IZA Bonn
}

Discussion Paper No. 2291

September 2006

\author{
IZA \\ P.O. Box 7240 \\ 53072 Bonn \\ Germany \\ Phone: +49-228-3894-0 \\ Fax: +49-228-3894-180 \\ Email: iza@iza.org
}

\begin{abstract}
Any opinions expressed here are those of the author(s) and not those of the institute. Research disseminated by IZA may include views on policy, but the institute itself takes no institutional policy positions.

The Institute for the Study of Labor (IZA) in Bonn is a local and virtual international research center and a place of communication between science, politics and business. IZA is an independent nonprofit company supported by Deutsche Post World Net. The center is associated with the University of Bonn and offers a stimulating research environment through its research networks, research support, and visitors and doctoral programs. IZA engages in (i) original and internationally competitive research in all fields of labor economics, (ii) development of policy concepts, and (iii) dissemination of research results and concepts to the interested public.
\end{abstract}

IZA Discussion Papers often represent preliminary work and are circulated to encourage discussion. Citation of such a paper should account for its provisional character. A revised version may be available directly from the author. 
IZA Discussion Paper No. 2291

September 2006

\section{ABSTRACT}

\section{Life Cycle Effects of Job Displacement in Brazil*}

This paper estimates the consequences of the decline of the Brazilian manufacturing sector for displaced workers. I estimate that earnings decline by nearly $50 \%$ after displacement relative to one year prior. About a quarter of the initial earnings loss is attributable to reduced hours of work rather than lower wages. However, hours recover fully within one year of displacement, while wages remain about a third lower. Allowing the displacement effect to differ by age yields a surprising U-shaped curve. Middle aged workers are hit hardest by a layoff, with younger and older workers relatively better off. For workers aged 35-40, the initial earnings loss reaches $70 \%$. This is a surprising finding because most theories of job loss predict a negative relationship between the wage loss on displacement and the length of tenure on the pre-displacement job, which is increasing in age. I account for these facts with a simple model in which the ratio of specific to general human capital reaches a peak at middle age. Young workers have little specific capital and a low specific-general human capital ratio. In the early years of one's career, specific capital (whether due to investments in specific skills or in search) accumulates much more rapidly than general human capital. Around ages 35 to 40, this trend reverses and the returns to general skills rise more rapidly. Thus, the accumulation of general skills serves to reduce the effect of job displacement at older ages despite increasing average job tenure. These findings suggest that major market reforms may have larger than anticipated effects because the primary losers are workers in the middle of their working life. This is also important from a welfare perspective because these workers are the most likely to fall through the cracks of social safety nets, which typically target younger and older workers.

JEL Classification: J21, J24, J63

Keywords: job displacement, structural adjustment, specific capital

Corresponding author:

Jasper Hoek

U.S. Department of the Treasury

International Affairs

1500 Pennsylvania Ave., NW

Washington, DC 20220

USA

E-mail: jhoek@umich.edu

\footnotetext{
* Thanks to John DiNardo, David Lam, Gary Solon, Jan Svejnar, Kathy Terrell, and participants at the Michigan labor seminar for helpful comments and suggestions. Remaining errors are my own.
} 


\section{INTRODUCTION}

Trade reforms implemented in Brazil in the 1980s and 1990s resulted in a major, persistent episode of job loss in Brazil's large urban areas. To date, the record of these reforms is mixed. On the plus side, there have been drastic improvements in productivity in the reformed sectors (Hay, 2001; Mueller, 2003). On the negative side, job creation has been a disappointment. At present, the net effect of trade reforms appears to be the disappearance of many "good jobs" from the labor market (IDB, 2004). Similarly, despite rising productivity in the manufacturing sector, trade reforms have not been accompanied by significant growth. The disappointing growth experience of Latin American countries after extensive trade liberalization calls into question whether "good policies" increase growth. Since trade reform has not yet been accompanied by growth in Latin America while most East Asian countries achieved spectacular growth under protectionist regimes, the cross-country evidence that free trade improves growth is very weak indeed, despite many economists' convictions to the contrary. (Easterly, 2004).

One potential reason for the dearth of good jobs is that much specific capital may have been lost during the transition to a market economy. If specific capital, which accumulates slowly, is an important input into production, then this may provide a plausible account of the missing link between market reform and growth. ${ }^{2}$

For the same reason, market reforms would be expected to have vastly different effects on different cohorts of workers. Workers who were already heavily invested in non-transferable skills would be expected to face much more acute adjustment costs than cohorts who arrived on the labor market more recently. ${ }^{3}$ Thus, there may be important welfare implications associated with this account of adjustment as well.

This paper examines adjustment costs associated with displacement from jobs in formerly protected maufacturing industries, paying particular attention to the size of the costs for workers of different ages. The conventional wisdom in the literature on this topic is that the costs of displacement are higher for older workers who are more likely to have lost a hightenure job. In a human capital framework, this can be attributed to a greater loss of specific capital. Podgursky and Swaim (1987), Kletzer (1989), and de la Rica (1992), and Farber (2003) all present findings along these lines for U.S. workers. This paper presents evidence that displacement costs are a U-shaped function of age, despite monotonically rising average job tenure and larger losses for high-tenure workers. To account for these facts, I show that if general and human capital both accumulate in unknown ways over the life cycle, the

\footnotetext{
${ }^{2}$ See Hall (1995) for a similar account of extended unemployment after a recession.

${ }^{3}$ Empirical studies of the transition economies provide mixed evidence for this phenomenon. Finta and Terrell (1997), Abraham and Vodpivec (1993), and Micklewright and Nagy (1997) all find that older workers had more difficulty leaving unemployment, while Ham et al (1998), Terrell and Sorm (1997), Lubyova and Ours (1997), Bellman et al (1995), Jones and Kato (1997), and Dushi (1997) find no evidence of age effects.
} 
displacement effect is an increasing function not only of the stock of specific capital, but of the ratio of specific to general human capital. Thus, a model in which this ratio reaches a peak at middle age is consistent with the findings. Young workers have little specific capital and a low specific-general human capital ratio. In the early years of one's career, specific capital (whether due to investments in specific skills or in search) accumulates more rapidly than general human capital. Around ages 35 to 40, this trend reverses and the returns to general skills rise more rapidly. Thus, the accumulation of general skills serves to reduce the effect of job displacement at older ages despite increasing average job tenure.

The data for this project come from the Brazilian Monthly Employment Survey (Pesquisa Mensal de Emprego, or PME), a panel employment survey of about 35,000 households per month, collected in six large urban areas in Brazil between 1982 and 2002. Each household is interviewed once a month for four months, dropped from the survey for eight months, and reinterviewed for four more months one year after the original interview. This structure allows for limited panel data analysis, which is explored below. However, most of the paper focuses on comparisons of former manufacturing workers just leaving unemployment to those just entering unemployment and those who are never displaced. The evidence presented here is consistent with very large adjustment costs, particularly for middle age workers. Earnings decline by up to $70 \%$ after displacement, partly because of reduced hours and partly because of reduced wages. Within the first year of displacement, hours conditional on working return to normal. Wages, however, remain one-third below pre-displacement levels.

The paper proceeds as follows: the next section documents some aspects of the decline in manufacturing employment. Section 3.3 discusses the estimation of displacement effects. Section 3.4 presents the main results of the paper, and Section 3.5 concludes.

\section{TRENDS IN MANUFACTURING EMPLOYMENT, 1982-2002}

Brazil's industrialization drive began in earnest in the years following World War II, when the government pursued an active import substitution industrialization (ISI) policy. ${ }^{4}$ The share of industry in GDP increased from $19.4 \%$ in 1939 to $27.2 \%$ in 1966 . The composition of manufactures also began to shift during this period, away from light industries such as textiles and food products in favor of consumer durables, chemicals, and other heavy industries. In the mid-1960s, when the initial dynamism associated with ISI had faded, the government changed its course and began to pursue an active policy of export promotion. The seven-year period that followed has been dubbed the "Brazilian miracle" because of the phenomenal growth rates Brazil experienced during this time. Industry expanded at

\footnotetext{
${ }^{4}$ The figures cited in this paragraph were taken from Baer (1995).
} 
rates of $12.6 \%$ per year between 1968 and 1974 with much of the growth again concentrated in heavy industries. Coffee's share of exports fell from $42 \%$ in the mid-1960s to $12.6 \%$ in 1974, while the share of manufactures rose from $7.2 \%$ to $27.7 \%$. After the first oil shock of the 1970s, balance of payments pressures began to surface. At this time, Brazil (under the newly-appointed president, Ernesto Geisel) made the conscious decision to pursue a debt-financed growth strategy. Thus, manufacturing employment and output continued to grow throughout the decade, but were accompanied by rapidly rising inflation and external debt. The cracks in this development strategy started to appear in 1980, and came to an abrupt halt throughout Latin America when Mexico defaulted on its debt in August 1982, and foreign credit to all countries in the region dried up.

1982 is also the year when our data begin. Figure 1 shows the share of manufacturing employment in Brazil's six largest cities during the 20 years following the debt crisis. Although there was a dip in manufacturing employment during the 1982-4 recession associated with the onset of the debt crisis, it was not until the late 1980s that manufacturing employment really began to fall. Beginning in 1987, non-tariff barriers were eliminated, but major trade reform occurred between 1990 and 1993, when tariffs were reduced across the board from an average of 40 percent to 13 percent (below prevailing levels in most East Asian countries). Figure 1 shows the rapid reversal of manufacturing employment that followed. Between the late 1980s and the late 1990s, the proportion of males aged 20 to 59 employed in manufacturing in Brazil's large metropolitan areas fell from about one-third to around 18 percent. The most precipitous decline occurred among the youngest workers: workers aged 20 to 29 were more likely to be employed in manufacturing in the early 1980s. By the end of the sample period, workers of all ages were about equally likely to be employed in manufacturing, with the exception of workers over age 50. These workers were much less likely to have been in manufacturing in the early 1980s, and also experienced a much milder decline during the 1990s.

Figure 2 presents the "cohort view" of the fraction employed in manufacturing industries, which provides some insight into how the rise and decline of manufacturing occured. Although we do not have data on the age distribution of manufacturing employment prior to 1982 , it is interesting that rise of manufacturing between the late 1940s and the late 1970s is reflected in rising fractions of successive cohorts employed in manufacturing in 1982. Moreover, the dip in manufacturing employment in the early 1980s is also reflected in a smaller share in manufacturing of the cohort aged 20 in 1982. This suggests that the growth of manufacturing employment in the previous four decades was fed by a larger flow of young cohorts entering manufacturing rather than a rising fraction of each cohort em- 
ployed in manufacturing. ${ }^{5}$ By contrast, the reversal of manufacturing appears to have been roughly cohort-neutral. Beginning in 1987, manufacturing began to decline in roughly equal proportions for all cohorts. Thus, since younger cohorts were more likely to be employed in manufacturing, the manufacturing decline had a larger overall impact on young workers; however, from the perspective of those employed in manufacturing, the impact was similar for workers of different ages.

The panel aspect of the data allows us to characterize the dynamics of manufacturing employment during the transition period. In Figure 3, monthly entry and exit rates through manufacturing employment are plotted for various age groups. These figures suggest that the manufacturing decline occurred in two phases. The first, from 1987 to 1992, was characterized by stable exit rates and sharply falling entry rates (which were themselves a reversal from depressed entry during the recession of the early 1980s). The amplitude of fluctuations in entry rates is clearly a decreasing function of age. Thus, the initial decline seems to have occurred by attrition with most of the adjustment shouldered by young workers. The second phase, from 1992 to 2002, is characterized by stable entry rates and rising exit rates. Exit rates are highest for the youngest and oldest age groups, but the change in exit rates was similar across age groups. Rising exit rates may reflect decreasing average job tenure or "reverse sorting" of the most entrenched workers out of manufacturing jobs. Some evidence for the reverse sorting explanation is that average job tenure among the unemployed who previously held manufacturing jobs rose steadily throughout the sample period (not shown). In the next section, we turn to the earnings consequences associated with these displacements.

\section{ESTIMATION STRATEGY}

There is a substantial literature that attempts to estimate the effect of displacement in the United States using the Panel Study of Income Dynamics (PSID), the Displaced Workers Surveys (DWS), and employer-employee linked data. ${ }^{6}$ Much of this literature has adopted the conceptual framework of a program evaluation problem to think about the estimation problem at hand. Viewed from this perspective, the task is to find a convincing way of comparing displaced workers' earnings at the time of displacement, $Y_{i t}^{T}$, with the unobserved earnings of those workers had they not been displaced, $Y_{i t}^{C}$. The true displacement effect,

\footnotetext{
${ }^{5}$ Topel and Kim (1994) have documented a similar phenomenon in South Korea. Although there are as yet no empirical studies on this topic, this pattern has the potential to discriminate between different models of economic growth (Klenow and Rodriguez-Clare, 1997). In particular, it may be consistent with one account of non-diminishing returns to human capital accumulation - human capital accumulation may cause growth because it is complementary to new technology.

${ }^{6}$ See, for example, Ruhm (1991) and Stevens (1997) for work using the PSID, Farber (1993, 2003) and Topel (1990) using the DWS, and Jacobson, Lalonde, and Sullivan (1993) who use administrative employer data linked with Social Security earnings records.
} 
$\Delta$, is the difference in expected earnings of these workers (the "treatment" group, $T$ ) in each state:

$$
\Delta=E\left[Y_{i t}^{T} \mid T\right]-E\left[Y_{i t}^{C} \mid T\right]
$$

Depending on one's emphasis, finding a suitable estimate for the second term on the right can be quite intractable indeed. As an example, consider the problem of determining whether separations are privately efficient. (If this were true, $\Delta$ would always be positive.) In this case, finding an appropriate control group is impossible because we can never know whether wages would have fallen in the absence of displacement. It is largely for this reason that empirical work on the theory of separations in the macroeconomics literature has made little headway (see, e.g., Hall, 1995). In contrast, the primary mission of the labor literature has been to find evidence of "scarring" effects of unemployment which naturally places emphasis on foregone earnings of displaced individuals along some presumably predictable non-displacement earnings path. Thus, labor economists have taken some degree of wage persistence as given whereas finding evidence of wage rigidity (or lack of it) is the whole point of the enterprise for macroeconomists. To some extent, therefore, any estimates of displacement effects must be seen as descriptive, despite best efforts to produce causal estimates.

\subsection{Panel Estimates}

Since households are surveyed over a period of up to 16 months, it is possible to estimate relatively short-run displacement effects by comparing labor market outcomes for a given group of manufacturing workers before and after job loss. This can be done by including a dummy variable indicating "post-displacement" in a regression on the panel of all displaced individuals before and after their displacement:

$$
Y_{i t}=X_{i t}^{\prime} \beta+\delta D_{i t}+\varepsilon_{i t}
$$

where $Y_{i t}$ is the $\log$ hourly wage or monthly earnings of individual $i$ at time $t, X_{i t}$ is a vector of potentially time-varying characteristics and $D_{i t}$ is a "post-displacement" dummy. Here, $\delta$ provides a measure of the displacement effect. The identifying assumption is that pre-displacement earnings are a good proxy for unobserved earnings in the absence of displacement:

$$
E\left[Y_{i, t-j} \mid T\right]=E\left[Y_{i t}^{C} \mid T\right]
$$

Thus, this estimator misses normal movements along the age-earnings profile as well as aggregate shocks that occur around the time of displacement. Given the rather short panel, foregone earnings are likely to be minimal (though aggregate shocks need not be). Never- 
theless, the sample of individuals who are continuously employed in a given manufacturing industry provides a suitable control group so that it is straightforward to estimate a difference-in-difference specification of the form:

$$
Y_{i t}=X_{i t}^{\prime} \beta+\alpha T_{i t}+\gamma D_{i t}+\delta\left(D_{i t} \times T_{i t}\right)
$$

where $D_{i t}$ again indicates post-displacement, and $T_{i t}$ is an indicator equal to one if an individual is ever displaced (the "treatment group"). The OLS estimate of $\delta$ yields the mean earnings/wage changes of displaced individuals relative to similar non-displaced individuals.

Although estimates from equations (3.2) and (3.4) provide a logical point of departure, several practical issues make this an unattractive method of estimating displacement effects with this data. The first is that the treatment group is difficult to define. Ideally, we would like to take the full sample of workers who were dismissed from manufacturing jobs for reasons beyond their control. In principle, we may then track them to their new jobs provided this happens within the survey period. The problem is is that, although we observe transitions out of manufacturing jobs, we do not generally observe the reason for the transition. In the PME survey, only individuals who are unemployed at the time of the survey are asked the conditions under which separation from the previous job took place. Below, panel estimates of displacement effects are presented separately for workers moving through unemployment who report being fired, workers moving out of the labor force before finding other work, and individuals who move directly from manufacturing to non-manufacturing jobs. Only the unemployment estimates can be regarded as involuntary transitions. Unfortunately, even reported information on the reason for dismissal must be taken with a bit of a grain of salt in the Brazilian context. The reason is that job security regulations in Brazil create perverse incentives for workers and firms to report separations as layoffs even if they are in fact voluntary. (Gonzaga, 2003; Paes de Barros et al., 2001). Thus, although the analysis below focuses on workers who report being fired, some of these workers may in fact have quit voluntarily. On the other hand, the analysis focuses on the manufacturing sector which experienced massive layoffs during the sample period, so that separations are quite likely to be involuntary.

A second issue is that since the panel is so short, we are virtually guaranteeing that "Ashenfelter dip" will be maximized. If wages deteriorate prior to displacement for the same reason that displacement occurs, then using a wage too close to displacement will understate the wage loss associated with displacement. ${ }^{7}$ In order to be able to track individuals from manufacturing to non-employment to non-manufacturing employment, the pre-displacement

\footnotetext{
${ }^{7}$ This issue has its origins in the literature evaluating the effect of training programs. See Ashenfelter (1978), Ashenfelter and Card (1985), and Card and Sullivan (1988), Dehejia and Wahba (1999).
} 
earnings/wage measure is limited to the month prior to displacement. For, individuals who move directly to new jobs, earnings from one year prior to displacement can be observed (but at the cost of not knowing the reason for separation and introducing measurement error). Other studies of the U.S. labor market have found that earnings may begin to deteriorate as far as five years prior to displacement in the U.S. (Jacobson, Lalonde, and Sullivan, 1993; Stevens, 1997). On the other hand, a study using administrative data in Brazil found virtually no pre-displacement deterioration in earnings (Menezes-Filho, 2003).

\subsection{Stacked Pre- and Post-Displacement Samples}

Given the constraints of the PME data, most of the paper focuses on a more robust alternative estimation strategy. I begin by constructing a "pre-displacement" sample and a "post-displacement" sample. The former are manufacturing workers observed entering unemployment and who report being fired. The latter are unemployed workers who report having been fired from a manufacturing job and are observed leaving unemployment for nonmanufacturing jobs. A regression similar to equation (3.2) can be estimated by stacking the pre- and post-displacement samples and including a "post-displacement sample" dummy. This simple difference estimator is subject to the same foregone earnings caveats as above. In principle, a suitable control group of non-displaced workers can be constructed by matching the pre- and post-displacement samples to similar non-displaced workers. Since the panel aspect is lost, however, this involves drawing samples (or weighting observations) in such a way as to mimic the distribution of pre-displacement employment times reported by the post-displacement sample. Farber (2003) uses this method to provide a control group of nondisplaced workers from the Current Population Survey for displaced workers in the DWS. However, since unemployment durations are typically very short - the median completed duration reported by the post-displacement sample is two months and $99 \%$ were unemployed less than a year - the benefit from difference-in-difference strategy is small compared to the DWS where workers are asked about displacement from the highest-tenure job in a threeto five-year recall window. Moreover, I will present evidence below that suggests that nondisplaced workers do not make an appropriate control group. For these reasons, I focus on simple difference estimates below.

The advantage of this estimation strategy is that it allows us to synthetically lengthen the survey period. In particular, a subset of the pre-displacement sample is also observed one year prior to displacement and a subset of the post-displacement sample is observed one year after displacement. Thus, denoting the first post-displacement employment month, $t$, and the last pre-displacement employment month, $t-1$, it is possible to estimate $\Delta_{t-13, t}$, $\Delta_{t-1, t}, \Delta_{t-1, t+12}$, and $\Delta_{t-12, t+12}$, where $\Delta_{t-j, t+k}$ refers the change in log earnings or wages 
between $t-j$ and $t+k$.

Measurement error is also drastically reduced in this case since identification of the displacement effect no longer comes from changes in industry, many of which are spurious. Furthermore, unlike if a person simply switches industries, a host of follow-up questions are asked to gather information about the details of unemployment and retrospective information about the previous job. This information can be used to provide consistency checks with information provided about employment in prior interviews.

\section{THE COSTS OF DISPLACEMENT}

Table 1 presents some descriptive statistics for various groups of workers originally employed in manufacturing and present for all eight interviews of the survey. This table gives an idea of the heterogeneity in employment and earnings outcomes among different samples used in this paper. The first column presents information about the sample of individuals who are observed working in the same (manufacturing) industry in all eight interviews. They are labeled the "never displaced" sample, although it is possible that they are displaced and re-hired in the same industry at some time during the eight months they are not observed. The second column contains statistics for the sample who are in the same industry in the first year of interviews (that is, in the first four interviews), but not necessarily in the second year of interviews. The third column presents results for the sample who switch industries in the first four interviews. To minimize measurement error, a "switch" is only confirmed if an individual is employed in the same industry for two months prior to the switch and two months after the switch. Given this restrictive definition, switches can only be observed for individuals between the second and third interviews. ${ }^{8}$ This eliminates transitions that last less than two months. The top set of rows contains information about the first year of interviews, while the bottom set presents the same information for the seventh interview (one year after the third interview).

Comparison of the three columns yields some interesting insights. The first is that nearly half of all transitions lead to non-employment and, of those, a substantial fraction enter unemployment. The unemployment rate of displaced workers is $23 \%(=16.8 /(16.8+56.4))$ in the months just after displacement. One year after displacement, this number falls sharply, to $5.5 \%(=4.4 /(4.4+75.2))$ compared to $2.5 \%$ unemployment among the sample that did not experience displacement a year before. This implies that part of the initial displacement effect is borne through unemployment rather than earnings, which is not accounted for in the regression estimates presented below (although we do show the effect

\footnotetext{
${ }^{8}$ Spurious transitions between industries appear to be an important phenomenon. Restricting the definition of transitions in this way reduces the number of transitions between the second and third interviews by half.
} 
on hours conditional on employment).

It is also clear that the sample of workers who experience some unemployment with displacement are much different from non-displaced workers and from displaced workers who make direct transitions to non-manufacturing industries. The average pre-displacement earnings of workers who enter unemployment upon displacement is only $\mathrm{R} \$ 400$ per month (in 1997 reais) compared to $\mathrm{R} \$ 627$ among the never-displaced sample and $\mathrm{R} \$ 654$ among those who make direct transitions. ${ }^{9}$ Moreover, although the probability of unemployment declines considerably one year after displacement, earnings remain roughly $15 \%$ below predisplacement levels for displaced workers regardless of how the transition occurred.

Finally, Table 1 also shows that individuals who leave manufacturing in the first year are much less likely to remain in the same industry one year later (33\% compared to $84 \%$ ). Their earnings are also likely to be lower if they do switch industries a second time. This suggests that another cost of displacement comes in the form of a higher probability of subsequent switches. Stevens (1997) presents similar evidence for the U.S.

Table 2 presents simple difference (SD) and difference-in-difference (DD) estimates of the displacement effect using the ever-displaced sample as the treatment group (column 3 in Table 1) and the never-displaced sample as control (column 1 in Table 1). Separate estimates are displayed for individuals who move through unemployment, through non-employment (out of the labor force), and direct transitions. The estimates compare the change in log earnings and wages between the second interview (the last pre-displacement month) and the seventh interview (one year after the first post-displacement month) for workers who report being employed during the seventh interview. For individuals who move directly between jobs, Table 2 also presents estimates of the change in log earnings and wages between the second and third interviews. The first four columns in Table 2 present regression estimates controlling for education, age, age squared, and a female dummy. The final four columns include industry, year, and city fixed effects as well. ${ }^{10}$ Since the treatment samples are quite small, the full specification is asking a lot of the simple difference estimator.

The only significant displacement effects reported in Table 2 are for the sample moving through unemployment. The SD estimates suggest that earnings and wages fall by roughly one quarter for these individuals (the coefficient on the Post dummy). Moreover, since wages among the control group of non-displaced workers tend to fall rather than rise, the SD estimator appears to slightly overstate the displacement effect. DD estimates suggest a decline of about 20 percent once the aggregate wage decline is accounted for. Note, however, that the ever-displaced sample has substantially lower mean earnings than the control group

\footnotetext{
${ }^{9}$ The questionnaire asks individuals to report their monthly earnings on the job they report having last week. The wage is calculated by dividing earnings by 4.3 times weekly hours.

${ }^{10}$ There are 47 industries, 21 years, and 6 cities.
} 
so that the appropriateness of the comparison is questionable.

Among the other samples (those moving out of the labor force and directly to other jobs) the results are notable for their complete lack of evidence of displacement costs. Indeed, the "impact effect" for workers making direct transitions is a quite precisely estimated zero. In the absence of data regarding the reasons for the transition from manufacturing employment, however, it is difficult to speculate much further about these estimates.

Turning to the "stacking estimator" described above, Table 3 presents means and standard deviations of demographic characteristics and labor market outcomes for the pre- and post-displacement samples, as well as the subsample of the pre-displacement group observed in the same industry one prior to displacement and the subsample of the post-displacement group one year after displacement. (Individuals observed a year later are not restricted to be in the same industry, since the initial displacement may be the cause of subsequent displacements as workers and firms sort to better matches.) Not surprisingly, these two samples are quite similar in observable characteristics. (In a steady state, we would expect those entering and leaving unemployment to be identical.) None of the demographic variables differ significantly from each other, although the post-displacement sample has a somewhat higher proportion of males and slightly higher job tenure on the previous job. It is also likely to be observed somewhat later in the sample period. The post-displacement sample has sharply lower earnings and wages, consistent with large losses upon displacement.

Figure 4 presents a visual comparison of wages for "similar" workers in the pre- and postdisplacement samples relative to the never-displaced sample. It is convenient to collapse the multi-dimensional vector of observable characteristics into a single propensity score. In order to do this, I first estimated a logit of the probability of being a pre-displacement worker relative to a non-displaced worker on education, age, age squared, and dummies for female, 27 manufacturing industries, 21 years, and 6 cities. The predicted values from this regression yield propensity scores which form the x-axis of Figure 4. Individuals with propensity scores close to zero have characteristics that resemble those of never-displaced workers. I then estimated a second logit, this time pooling the post-displacement sample with the never-displaced sample. The predicted values again produced a propensity score. Finally, I divided the range of the propensity scores into 100 1-percentage-point bins and calculated the mean log earnings and wages of pre- and post-displacement workers and their non-displaced counterparts in each bin. Figure 4 plots these means for each group. The size of the marker is a function of the square root of the sample size within each bin, so that the distribution of each sample across the range of scores can be gleaned from the figure as well. Since the never-displaced sample is, in fact, larger than the pre- and post-displacement samples, the distribution of each group is concentrated in the lower part of the propensity 
score range.

The figure reveals a roughly constant difference in mean earnings between the pre- and post-displacement sample of about $-0.5 \mathrm{log}$ points for earnings and -0.4 for wages across the range of the propensity score. Since the pre- and post-displacement samples are not identical, however, the propensity scores are not strictly comparable, although they are very close. If they were identical, as they would be with a panel, the mean earnings and wages of non-displaced workers would be the same across the propensity score range regardless of whether it was estimated using the pre-displacement sample or the post-displacement sample as the treatment group. The similarity of the mean earnings and wages of the non-displaced workers relative to each displacement sample is thus driven by the similarity of the pre- and post-displacement samples. It is also clear that the there is a non-negligible gap between the pre-displacement sample and the non-displaced sample, which reflects differences in unobservables between the two groups. This unobservables gap is not constant across the range of the propensity score, and grows quite large as the score approaches zero where most of the sample is concentrated. ${ }^{11}$ As with the panel estimates above, this suggests that the never-displaced sample may not provide a suitable control group for displaced workers.

The main estimates of the average displacement effects are presented in Table 4. For each of four combinations of pre- and post-displacement times $(t-13$ to $t, t-1$ to $t, t-13$ to $t+12$, and $t-1$ to $t+12$ ), this table presents SD estimates obtained by applying OLS to equation (2) on the stacked pre- and post-displacement samples as described in the previous section. The columns associated with each displacement effect are labeled $\Delta_{t-13, t}, \Delta_{t-1, t}, \Delta_{t-13, t+12}$, and $\Delta_{t-1, t+12}$, respectively, where $t$ denotes the first post-displacement month in which a worker is found working, $t-1$ the first pre-displacement month.

The average displacement effects shown in Table 4 are very large. The estimate of $\Delta_{t-13, t}$ is -0.678 for earnings, corresponding to a $49 \%$ fall in earnings. ${ }^{12}$ Compared to the month immediately preceding layoffs, earnings decline by $40 \%$. There is also evidence of moderate recovery in earnings, however. Earnings are estimated to fall by $32 \%$ from one year prior to one year after displacement, and by $19 \%$ from one month prior to one year after displacement.

A significant portion of the initial earnings decline is attributable to reduced hours rather than reduced wages. Since hourly wages are calculated by dividing monthly earnings by 4.3 times the reported weekly hours, the change in log earnings can be decomposed additively into a portion attributable to wages and a portion attributable to hours worked. The second

\footnotetext{
${ }^{11}$ Since the pre-displacement earnings and wages correspond to the month immediately prior to displacement, a part of this gap may reflect deterioration in earnings that is a consequence of impending displacement and should therefore be included in the displacment effect. The estimates presented below show some evidence of this; however, the one-year pre-displacement sample is not large enough to conduct the same exercise.

${ }^{12}$ Since the changes are so large, the log approximations given by the coefficients are misleading. The true effect is $e^{\delta}-1$, where $\delta$ is the estimated coefficient on the displacement dummy.
} 
set of rows in Table 4 show the effect of displacement on wages, and the third shows the effect on hours worked. Wages fall by $40 \%$ and $32 \%$ in the first month after displacement relative to one year and one month prior, respectively. Thus, reduced hours (conditional on working) account for about one-fifth of the initial earnings decline. However, as evidenced by the equality of earnings and wage effects, hours recover fully within a year of displacement. By contrast, the effect on wages is quite persistent. One year after displacement, wages remain $32 \%$ lower than one year prior. Extrapolating forward from this rate (admittedly, a somewhat reckless exercise) suggests that it would take ten years before the wage reached $95 \%$ of its pre-displacement level.

The results in Table 4 are not directly comparable to those in Table 2 because the earnings and wage changes for the panel estimates (Table 2) refer to differences across one calendar year while the stacking estimates (Table 4) do not account for the time spent in unemployment. However, since the majority of the sample spends less than two months in unemployment, the estimates in the fourth column in Table $4\left(\Delta_{t-1, t+12}\right)$ are the most comparable to the unemployment estimates in Panel A of Table 2, and in fact they are quite similar.

Table 5 presents a robustness check to test the sensitivity of the results to inflation. Brazil experienced enormous fluctuations in inflation during the sample period, including two hyperinflations (in 1989 and 1993) juxtaposed with periods of relative price stability and almost everything in between. Although the price index used to deflate wages was constructed with considerable care and reveals no unusual spikes in average wages over the period, it is only a monthly index. ${ }^{13}$ With prices rising at $30 \%$ or more a month and households surveyed throughout each month, there is of necessity a substantial amount of measurement error in real earnings. The first three columns in Table 5 contain estimates of $\Delta_{t-1, t}$ for months of low inflation (less than $6 \%$ per month - roughly $100 \%$ per year), medium inflation (6-20\% per month), and high-inflation (more than $20 \%$ per month), respectively. Since inflation is correlated with other macroeconomic variables that may genuinely affect the cost of displacement, it is likely that differences in the estimates also reflect other "time effects." Broadly speaking, low-inflation months are concentrated in the alternate growth and stagnation period of the late 1990s, medium-inflation months in the recession of the early 1980s, and high-inflation months in the stagnation of the late 1980s. In order to get around this problem, the second set of three columns limits the sample to the years 1986, 1991 and 1994, which are the only three years in the sample which contain relatively equal amounts of low-, medium-, and high-inflation months. The results do not show a systematic relationship between displacement effects and inflation. Displacement effects

\footnotetext{
${ }^{13}$ This index was provided by researchers from the Institute of Applied Economic Research (IPEA) in Rio de Janeiro.
} 
are similar for low- and high-inflation months, and are larger in the full sample for mediuminflation months (but lower in the restricted sample). In all cases, they are within $0.1 \mathrm{log}$ points of each other. Furthermore, the precision of the estimates does not decline noticeably with inflation.

\subsection{Displacement Effects by Age and Tenure}

Are displacements especially painful for older workers? There are many reasons to suppose that this would be the case. If job-specific human capital is an important component of productivity, then workers who have accumulated much specific capital will experience greater wage losses upon termination. Specific capital may be the result of prior investments in job-specific skills (Becker, 1975) or investments in search (Jovanovic, 1979). Moreover, these workers will be less likely to experience termination, because the outside option to firms and workers is lower when match-specific investments will be lost. Alternatively, heterogeneity among workers and firms may generate the same patterns. Firms with less volatile labor demand will be more likely to invest in specific capital, and therefore less likely to fire workers. Similarly, if there are good jobs and bad jobs, workers in good jobs will be less likely to quit, and will experience greater losses if they are fired (Farber, 1999). All of these theories share in common two predictions: a negative relationship between job tenure and the incidence of job termination and a positive relationship between job tenure and wage loss upon displacement. ${ }^{14}$

If match quality is an experience good, in the sense that workers and firms need to try each other out before knowing how good the quality of their match will be, then older workers who have had more time to shop around in the labor market ought to be found in better matches on average. Again, however, to the extent that this is true the effect works through job tenure and not age per se. Older workers would be expected to have higher job tenure on average, but the wage loss associated with displacement should be the same (in expectation) for workers who randomly arrive at the same job tenure at different ages.

To answer the empirical question of how the displacement effect differs by age, the regressions from the previous section were re-estimated interacting the displacement indicator with dummies for each single year of age. The matching estimator does not allow for an easy way to estimate multiple treatment effects, so the rest of the paper focuses on results from simple difference analysis. ${ }^{15}$ Figure 5 presents a 5 -year-centered moving average of $\Delta_{t-13, t}, \Delta_{t-1, t}$, and $\Delta_{t-1, t+12}$ at each age for earnings (solid lines) and wages (dashed lines).

\footnotetext{
${ }^{14}$ For the same reason, the literature has found it very difficult to distinguish between competing explanations (Farber, 1999).

${ }^{15}$ The OLS regressions controlling for lagged income can incorporate multiple treatment effects. The results are very similar to the ones that follow, so I focus on the difference estimates.
} 
There are several interesting features of Figure 5. First, the age-loss function is U-shaped, with the youngest and oldest workers experiencing the smallest losses. The inflection point occurs between ages 35 and 40. Thus, displacement hurts not older workers, but middleaged workers, the most. However, the results of the previous section carry over across age groups. A sizeable portion of the initial impact on earnings is attributable to reduced hours (the wage loss is much smaller than the earnings loss), but by one year after displacement, hours worked have fully recovered at all ages. And, as before, the difference estimates show a substantial deterioration in wages prior to displacement.

The finding of a U-shaped age-loss function is surprising. In the context of the job mobility literature, however, the most natural candidate explanation for this finding would be that older workers are, for whatever reason, not in more valuable matches on average. If this is true, we should expect two things: that the displacement effect is indeed increasing with tenure, and that the relationship between tenure and age among unemployed workers is itself U-shaped. Figure 6 plots the impact effect of displacement on wages by age (in Panel A) and by tenure (Panel B), together with $95 \%$ confidence intervals. Here, we see that, in contrast with the age-loss function, which is well-described by a quadratic, the tenure-loss function is monotonically decreasing (i.e., wage losses are increasing) with tenure. The estimates are quite precise at younger ages and shorter tenures, where sample sizes are largest.

Is job tenure a U-shaped function of age? Figure 7 plots the average completed job tenure on the previous job among unemployed workers by age. Far from being U-shaped, tenure is a remarkably linear function of age, accumulating at a rate of about one year per every ten years of labor market experience. Thus, while the dominant themes of the previous theoretical discussion seem to apply, they cannot account for the patterns of wage loss observed for displaced workers of different ages.

\subsection{Age v. Tenure: An Illustrative Decomposition}

The results of the previous section suggest that there are other factors at work besides the standard specific capital/heterogeneity stories. One explanation for this finding is that young and old workers have a greater proportion of their human capital in general rather than specific skills. Since the displacement effects estimated here and elsewhere are expressed as a proportion of pre-displacement earnings, larger displacement effects must reflect not merely more specific capital, but a higher ratio of specific to general capital. Thus, while specific capital is generally increasing with age and will tend to cause larger wage losses upon displacement, this by itself does not guarantee a larger displacement effect because general human capital may also accumulate with age. 
To see this more clearly, suppose that wages can be expressed as the sum of returns to general and specific skills,

$$
w\left(a_{t}, T_{t}\right)=g\left(a_{t}\right)+s\left(T_{t}\right)
$$

where $g\left(a_{t}\right)$ is a function of unknown form that relates a person's general skills to her age, (or more accurately, her labor market experience), and $s\left(T_{t}\right)$ is function that relates specific skills to tenure on the current job. In this case, the log of the wage can be approximated by:

$$
\ln w\left(a_{t}, T_{t}\right) \approx \alpha \ln g\left(a_{t}\right)+(1-\alpha) \ln s\left(T_{t}\right)
$$

where $\alpha$ is the share of the wage attributable to returns to specific skills. Assuming the general human capital that accumulates during displacement is negligible and that specific capital on a new job is zero, the effect of displacement at time $t$ on wages is equal to:

$$
\ln w_{t}-\ln w_{t-1}=(1-\alpha)\left[\ln s(0)-\ln s\left(T_{t-1}\right)\right]=-(1-\alpha) \ln s\left(T_{t-1}\right)
$$

The general human capital term cancels out leaving only the change in specific capital (which is a function only of prior tenure) in the displacement effect. Indeed, this is the motivation behind the literature that tries to test theories of specific human capital based on the experiences of displaced workers (Farber, 1994). However, notice that the displacement effect is also a function of $\alpha$, the share of the wage that remunerates general skills. The smaller is this share, the larger is the displacement effect. In general, $\alpha$ will be a complicated function of previous general and specific human capital accumulation.

We can illustrate these two components of the displacement effect in the following way. First, the displacement effect implied by the distribution of tenure across age groups can be calculated by averaging the displacement effect associated observed levels of previous job tenure across all individuals of a particular age. I call this the "tenure effect." Comparing this function to the "total age effect" given by the age-loss functions estimated previously yields some insight into the importance of residual displacement effects. Figure 8 plots each of these functions for the effect of displacement on wages one month prior to one month post-displacement $\left(\Delta_{t-1, t+1}\right)$. The tenure effect increases roughly linearly with age - older workers have higher tenure and therefore tend to experience larger losses. However, for younger workers (under age 25), the total displacement effect is smaller than would be implied by their average tenure. According to the model presented here, this is because younger workers have relatively large shares of general human capital. Thus, they experience mild wage losses relative to their tenure. Wage losses associated with displacement rise sharply between age 20 and 35 , so that by age 35 the displacement effect is much larger than the average tenure of 35-year-olds implies. This suggests that remuneration for specific 
skills rises rapidly relative to general skills during this phase, making displacement particularly painful for middle age workers. From age 35 onward, displacement effects become progressively milder despite increasing average job tenure, suggesting that general skills accumulate much more rapidly during this phase.

This appears to be a plausible account of an average career. In the early years, workers' human capital consists mostly of the skills learned in school. With experience, skills learned on the job rise rapidly as do improvements in match quality through sorting, but these aspects of productivity reach diminishing returns by middle age. At this point, the returns to general skills (such as organizational efficiency and managing younger workers) begin to become more important. Although I am unaware of evidence of the latter phenomenon (rising returns to general skills later in life), the former (rising returns to specific skills early in life) is consistent with Topel and Ward's (1992) analysis of young men in the U.S. labor market.

\section{CONCLUSION}

This paper has presented evidence of sizable earnings losses associated with displacement from formerly protected manufacturing jobs. I estimate that earnings decline by nearly $50 \%$ after displacement relative to one year prior. About one-fifth of the initial earnings loss is attributable to reduced hours of work rather than lower wages. However, hours recover fully within one year of displacement, while wages remain about a third lower.

Allowing the displacement effect to differ by age yields a surprising U-shaped curve. Middle aged workers are hit hardest by a layoff, with younger and older workers relatively better off. For workers aged 35-40, the initial earnings loss reaches 70\%. This is a surprising finding because most theories of job loss predict a negative relationship the wage loss on displacement and the length of tenure on the pre-displacement job, which is increasing in age.

A possible explanation for this finding is that the ratio of specific to general human capital reaches a peak at middle age. Young workers have little specific capital and a low specificgeneral human capital ratio. In the early years of one's career, specific capital (whether due to investments in specific skills or in search) accumulates much more rapidly than general human capital. Around ages 35 to 40, this trend reverses and general human capital begins to accumulate more rapidly. Thus, while specific human capital may continue to rise with age, the accumulation of general skills serves to reduce the effect of job displacement at older ages.

These findings suggest that major market reforms may have larger than anticipated effects because the primary losers are workers in the middle of their working life. This is 
also important from a welfare perspective because these workers are the most likely to fall through the cracks of social safety nets, which typically target younger and older workers. 


\section{REFERENCES}

[1] Abraham, K. and M. Vodopivec, "Slovenia: A Study of Labor Market Transitions," Mimeo (World Bank), Washington DC, 1993.

[2] Ashenfelter, Orley, "Estimating the Effect of Training Programs on Earnings," Review of Economics and Statistics, 60, February 1978, 47-57.

[3] Ashenfelter, Orley and David Card, "Using the Longitudinal Structure of Earnings to Estimate the Effect of Training Programs, " Review of Economics and Statistics,67, Novermber 1985, 648-660.

[4] Baer, Werner, The Brazilian Economy: Growth and Development, Westport: Praeger, 1995.

[5] Becker, Gary S., "Human Capital: A Theoretical and Empirical Analysis with Special Reference to Education," Cambridge, MA: NBER 1964.

[6] Bellman, Lutz, Saul Estrin, Hartmut Lehmann and Jonathan Wadsworth, "The Eastern German Labor Market in Transition: Gross Flow Estimates from Panel Data," Journal of Comparative Economics, 20, 1995, 139-70.

[7] Card, David and Daniel Sullivan, "Measuring the Effect of Subsidized Training Programs on Movements In and Out of Unemployment," Econometrica, 56, May 1988, 497-530.

[8] Dehejia, Rajeev and Sadek Wahba, "Causal Effects in Non-Experimental Studies: ReEvaluating the Evaluation of Training Programs, "Journal of the American Statistical Association, 94, December 1999, 1053-1062.

[9] de la Rica, Sara, "Displaced Workers in Mass Layoffs: Pre-Displacement Earnings Losses and the Unions Effect," Working Paper No. 303, Industrial Relations Section, Princeton University, June 1992.

[10] Dushi, I., "Labor Market, Unemployment, and the Impact of Training Programs in the Transition Economies: The Case of Albania," mimeo. (CERGEI-EI Prague), 1997.

[11] Easterly, William, "National Policies and Economic Growth: A Reappraisal," mimeo., New York University, February 2004.

[12] Farber, Henry, S., “ The Incidence and Costs of Job Loss: 1982-91," Brookings Papers on Economic Activity: Microeconomics, 1993, 73-119. 
[13] Farber, Henry, S., "The Analysis of Interfirm Worker Mobility," Journal of Labor Economics, 12, 1994, 554-593.

[14] Farber, Henry, S., "Mobility and Stability: The Dynamics of Job Change in Labor Markets," in Ashenfelter, O., and David Card (eds.), Handbook of Labor Economics, Volume 3, 1999, 2439-2483.

[15] Farber, Henry, S., "Job Loss in the United States: 1981-2001," NBER, May 2003.

[16] Finta, Jana and Katherine Terrell, "Gender Differences in Flows Across Labor Market States in the Czech Republic," unpublished paper (University of Michigan, Ann Arbor), 1997.

[17] Gonzaga, Gustavo, "Labor Turnover and Labor Legislation in Brazil," Economia, 4(1), Fall 2003, 165-222.

[18] Hall, Robert E., "Lost Jobs," Brookings Papers on Economic Activity, 0(1), 1995, 22156.

[19] Ham, J., Jan Svejnar, and Katherine Terrell, "Unemployment and the Social Safety Net During Transitions to a Market Economy:Evidence from the Czech and Slovak Republics," American Economic Review, 88(5), 1117-42.

[20] Hay, Donald, "The Post-1990 Brazilian Trade Liberalisation and the Performance of Large Manufacturing Firms: Productivity, Market Share and Profits," Economic Journal, 111(473), July 2001, 620-41.

[21] Inter-American Development Bank, Good Jobs Wanted, 2004.

[22] Jacobson, Louis, Robert LaLonde and Daniel Sullivan, "Earnings Losses of Displaced Workers," American Economic Review, 83(4),September 1993, 685-709.

[23] Jones, Derek C. and Takao Kato, "The Nature and Determinants of Labor Market Transitions in Former Communist Economist: Evidence from Bulgaria," Industrial Relations, 36(2), 1997, 229-254.

[24] Jovanovic, Boyan, "Job Matching and the Theory of Turnover," Journal of Political Economy, 87, 1979, 972-990.

[25] Klenow, Peter J. and Andrés Rodriguez-Clare, "Economic Growth: A Review Essay," Journal of Monetary Economics, 40, 1996, 597-617.

[26] Lori G. Kletzer, "Returns to Seniority After Permanent Job Loss," American Economic Review, 79, 1989, 536-543. 
[27] Lubyova, Martina and Jan van Ours, "The Matcing process in Labour Markets in Transition," Working Paper no. 13 (East European HIS, Vienna), 1997.

[28] Menezes-Filho, Naercio, "The Costs of Displacement in Brazil: Is Human Capital Firm-Specific?" mimeo., University of São Paulo, 2003.

[29] Micklewright, J. and G. Nagy, "The Implications of Exhausting Unemployment Insurance Entitlement in Hungary," Occasional papers No. 58, Economic and Social Policy Series, United Nations Children's Fund, 1997.

[30] Paes de Barros, Ricardo, Corseuil, Carlos Henrique and Foguel, Miguel, "Os Incentivos Adversos e a Focalização Dos Programas de Proteção ao Trabalhador no Brasil," Texto para Discussão 784, Instituto de Pesquisa Econômica Aplicada (IPEA), 2001.

[31] Podgursky, Michael and Paul Swaim, "Job Displacement Earnings Loss: Evidence from the Displaced Worker Survey," Industrial and Labor Relations Review, 41, October 1987, 17-29.

[32] Rosenbaum, P., and D. Rubin, "The Central Role of the Propensity Score in Observational Studies for Causal Effects," Biometrika, 70(1), April 1983, 41-55.

[33] Rosenbaum, P., and D. Rubin, "Constructing a Control Group Using Mulitvariate Matched Sampling Methods that Incorporate the Propensity," American Statistician, 39(1), February 1985, 33-38.

[34] Ruhm, Christopher J. "Are Workers Permanently Scarred by Job Displacements?" American Economic Review, 81(1), 1991, 319-324.

[35] Stevens, Ann Huff, "Persistent Effects of Job Displacement: The Importance of Multiple Job Losses," Journal of Labor Economics, 15(1), January 1997, 165-88.

[36] Terrell, Katherine and Vit Sorm, "Labor Market Policies and Unemployment in the Czech Republic," Journal of Comparative Economics, 27(1), March 1999, 33-60.

[37] Topel, Robert, "Specific Capital and Unemployment: Measuring the Costs and Consequences of Job Loss," Carnegie Rochester Conference Series on Public Policy, 33, 1990, 181-214.

[38] Topel, Robert and Michael Ward, "Job Mobility and the Careers of Young Men," Quarterly Journal of Economics, 107(2), May 1992, 439-479.

[39] Topel, Robert H. and Dae Il Kim, "Labor Markets and Economic Growth: Lessons from Korea's Industrialization, 1970-90," in Freeman, Richard B. and Lawrence F. Katz 
(eds.), Differences and Changes in Wage Structures, Chicago: University of Chicago Press, 1995, 227-64. 
Table 1. Employment and Earnings of Non-Displaced, Displaced, and Yet-to-be Displaced Manufacturing Workers

\begin{tabular}{|c|c|c|c|}
\hline & Never switch & $\begin{array}{l}\text { No switch in first } \\
\text { year of interviews }\end{array}$ & $\begin{array}{l}\text { Exactly one switch in } \\
\text { first four interviews } \\
\text { (between 2nd and 3rd) }\end{array}$ \\
\hline Sample size & 198,560 & 304,848 & 10,912 \\
\hline \multicolumn{4}{|l|}{ First year of interviews: } \\
\hline Percent working after second interview & 100 & 100 & 56.4 \\
\hline Pre-switch monthly earnings if working & 627 & 601 & 654 \\
\hline Pre-switch weekly hours if working & 44.6 & 44.3 & 43.4 \\
\hline Pre-switch wage if working & 3.40 & 3.28 & 3.61 \\
\hline Post-switch monthly earnings if working & .. & .. & 554 \\
\hline Post-switch weekly hours if working & .. & .. & 43.1 \\
\hline Post-switch wage if working & .. & .. & 3.28 \\
\hline Percent unemployed & 0 & 0 & 16.8 \\
\hline Percent fired from previous job, if unemployed & .. & .. & 84.3 \\
\hline Percent who quit previous job, if unemployed & .. & .. & 15.7 \\
\hline Pre-unemployment monthly earnings & .. & .. & 400 \\
\hline Pre-unemployment weekly hours & .. & .. & 43.8 \\
\hline Pre-unemployment wage & .. & .. & 2.22 \\
\hline Percent not in labor force (NILF) & 0 & 0 & 26.8 \\
\hline Pre-NILF monthly earnings & .. & .. & 361 \\
\hline Pre-NILF weekly hours & .. & .. & 40.9 \\
\hline Pre-NILF wage & .. & .. & 2.12 \\
\hline \multicolumn{4}{|l|}{ One year later: } \\
\hline Percent working & 100 & 93.0 & 75.2 \\
\hline Percent in same industry if working & 100 & 84.0 & 33.1 \\
\hline Monthly earnings if working in same industry & 599 & 595 & 570 \\
\hline Weekly hours if working in same industry & 44.1 & 43.9 & 43.2 \\
\hline Wage if working in same industry & 3.30 & 3.29 & 3.23 \\
\hline Percent in different industry if working & 0 & 7.0 & 36.5 \\
\hline Monthly earnings if working in different industry & .. & 525 & 541 \\
\hline Weekly hours if working in different industry & .. & 43.4 & 42.7 \\
\hline Wage if working in different industry & .. & 2.93 & 3.11 \\
\hline Percent previously non-employed if working & 0 & 0.0 & 30.4 \\
\hline Monthly earnings if working in different industry & .. & .. & 329 \\
\hline Weekly hours if working in different industry & .. & .. & 42.0 \\
\hline Wage if working in different industry & .. & .. & 1.91 \\
\hline Percent unemployed & 0 & 2.4 & 4.4 \\
\hline Percent fired from previous job, if unemployed & .. & 84.8 & 81.7 \\
\hline Percent who quit previous job, if unemployed & .. & 15.2 & 18.3 \\
\hline Percent not in labor force & 0 & 4.6 & 20.5 \\
\hline
\end{tabular}

Source: Author's calculations from the PME. All earnings and wages figures are expressed in 1997 reais. Sample includes all individuals aged 20-59 present for all eight interviews of the survey. Respondents are interviewed once a month for four months, dropped from the sample for eight month, and re-interviewed for four more months. 
Table 2. Panel Estimates of Earnings and Wage Changes Upon Displacement from Manufacturing to Service Employment

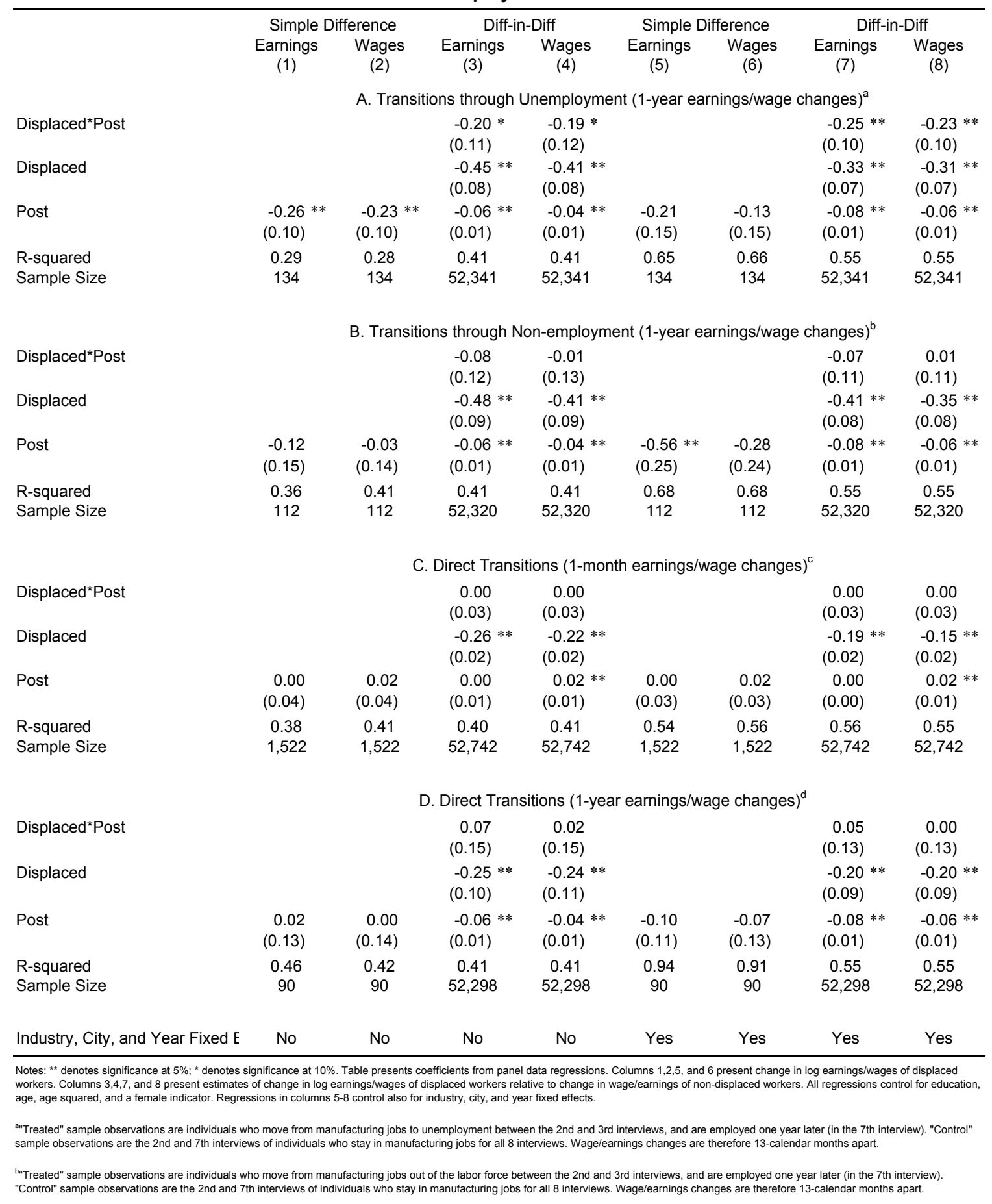


Table 3. Descriptive Statistics of Manufacturing Workers Ages 20-59 Observed Before and After Displacement to Non-manufacturing Employment via Unemployment, Brazil, PME, 1982-2002

\begin{tabular}{|c|c|c|c|c|c|c|c|c|}
\hline \multirow[b]{3}{*}{ Time relative to displacement: } & \multicolumn{4}{|c|}{ Fired } & \multicolumn{4}{|c|}{ Quit } \\
\hline & \multicolumn{2}{|c|}{$\begin{array}{c}\text { Pre-displacement } \\
\text { sample }\end{array}$} & \multicolumn{2}{|c|}{$\begin{array}{c}\text { Post- } \\
\text { displacement } \\
\text { sample } \\
\end{array}$} & \multicolumn{2}{|c|}{$\begin{array}{c}\text { Pre-displacement } \\
\text { sample }\end{array}$} & \multicolumn{2}{|c|}{$\begin{array}{c}\text { Post- } \\
\text { displacement } \\
\text { sample } \\
\end{array}$} \\
\hline & $\mathrm{t}-13$ & $\mathrm{t}-1$ & $\mathrm{t}$ & $t+12$ & $t-13$ & $\mathrm{t}-1$ & $\mathrm{t}$ & $\mathrm{t}+12$ \\
\hline Sample size & 1,428 & 11,670 & 7,824 & 2,495 & 264 & 2,701 & 1,835 & 583 \\
\hline \multirow[t]{2}{*}{ Earnings } & 415 & 345 & 210 & 269 & 366 & 326 & 240 & 290 \\
\hline & 464 & 400 & 246 & 292 & 367 & 371 & 631 & 289 \\
\hline \multirow[t]{2}{*}{ Hours } & 43.9 & 38.7 & 38.5 & 43.1 & 43.2 & 39.9 & 38.2 & 42.8 \\
\hline & 7.9 & 14.9 & 14.2 & 9.6 & 7.4 & 13.8 & 14.4 & 10.9 \\
\hline \multirow[t]{2}{*}{ Wage } & 2.34 & 2.03 & 1.39 & 1.53 & 2.16 & 1.91 & 1.55 & 1.65 \\
\hline & 2.79 & 2.82 & 3.59 & 2.02 & 2.24 & 2.38 & 3.04 & 1.66 \\
\hline \multirow[t]{2}{*}{ Education } & 6.3 & 6.5 & 6.5 & 6.4 & 6.8 & 6.7 & 6.8 & 6.9 \\
\hline & 3.5 & 3.6 & 3.6 & 3.5 & 3.6 & 3.6 & 3.7 & 3.7 \\
\hline \multirow[t]{2}{*}{ Age } & 32.9 & 30.5 & 30.8 & 30.8 & 30.5 & 28.9 & 28.9 & 29.4 \\
\hline & 9.0 & 8.7 & 8.8 & 8.6 & 8.0 & 8.2 & 8.0 & 7.9 \\
\hline \multirow[t]{2}{*}{ Percent Female } & 21.1 & 21.9 & 19.7 & 17.6 & 24.5 & 27.7 & 33.2 & 29.7 \\
\hline & 40.8 & 41.3 & 39.8 & 38.1 & 43.1 & 44.8 & 47.1 & 45.7 \\
\hline \multirow[t]{2}{*}{ Tenure on previous job (years) } & 3.4 & 2.0 & 2.3 & 3.4 & 2.5 & 1.5 & 1.7 & 2.5 \\
\hline & 4.0 & 3.2 & 3.4 & 4.0 & 3.5 & 2.5 & 2.8 & 3.5 \\
\hline \multirow[t]{2}{*}{ Year } & 90.4 & 90.8 & 91.5 & 89.9 & 88.9 & 89.3 & 89.8 & 88.7 \\
\hline & 5.5 & 6.0 & 6.0 & 5.5 & 4.6 & 5.4 & 5.6 & 5.2 \\
\hline
\end{tabular}


Table 4. Effect of Displacement from Manufacturing Job on Log Earnings and Wages, 6 Cities, Brazil, 1982-2002

\begin{tabular}{|c|c|c|c|c|}
\hline & $\Delta_{\mathrm{t}-13, \mathrm{t}}$ & $\Delta_{\mathrm{t}-1, \mathrm{t}}$ & $\Delta_{t-13, t+12}$ & $\Delta_{\mathrm{t}-1, \mathrm{t}+12}$ \\
\hline Earnings & $\begin{array}{l}-0.678^{* *} \\
(0.022)\end{array}$ & $\begin{array}{l}-0.512 \text { ** } \\
(0.010)\end{array}$ & $\begin{array}{l}-0.386 \text { ** } \\
(0.029)\end{array}$ & $\begin{array}{l}-0.208 \text { ** } \\
(0.013)\end{array}$ \\
\hline R-Squared & 0.36 & 0.41 & 0.44 & 0.41 \\
\hline Wages & $\begin{array}{l}-0.509 \text { ** } \\
(0.021)\end{array}$ & $\begin{array}{l}-0.383^{* *} \\
(0.010)\end{array}$ & $\begin{array}{l}-0.386 \text { ** } \\
(0.030)\end{array}$ & $\begin{array}{l}-0.228 \text { ** } \\
(0.014)\end{array}$ \\
\hline R-Squared & 0.34 & 0.38 & 0.41 & 0.39 \\
\hline $\begin{array}{l}\text { Hours, conditional on } \\
\text { working }\end{array}$ & $\begin{array}{l}-0.169 * * \\
(0.012)\end{array}$ & $\begin{array}{l}-0.129 * * \\
(0.005)\end{array}$ & $\begin{array}{r}0.000 \\
(0.013)\end{array}$ & $\begin{array}{l}0.019 \text { ** } \\
(0.006)\end{array}$ \\
\hline R-Squared & 0.06 & 0.06 & 0.05 & 0.03 \\
\hline Sample Size & 9,246 & 19,474 & 3,921 & 14,149 \\
\hline
\end{tabular}

Notes: ${ }^{* *}$ denotes siginificance at $5 \%$ level. Time t denotes the first post-displacement month with positive earnings. Each column corresponds to a combination of pre- and post-displacement times (13 months prior to 1 month post, 1 month prior to 1 month post, 13 months prior to 1 year post, and 1 month prior to 1 year post, respectively). Estimates compare earnings and wages of individuals leaving unemployment to those just entering unemployment, controlling for education, age, age squared, female, dummies for each industry at $\mathrm{t}-1$, and dummies for each city and year. 
Table 5. Robustness Checks of Impact Effects of Displacement $\left(\Delta_{t-1, t}\right)$ : Low, Medium, and High Inflation Periods, 6 Cities, Brazil, 1982-2002

\begin{tabular}{|c|c|c|c|c|c|c|}
\hline & \multicolumn{3}{|c|}{ All years } & \multicolumn{3}{|c|}{1986,1991, and 1994 only $^{\mathrm{d}}$} \\
\hline & Low $^{a}$ & Medium $^{\mathrm{b}}$ & $\mathrm{High}^{\mathrm{c}}$ & Low $^{a}$ & Medium $^{\mathrm{b}}$ & High $^{\mathrm{c}}$ \\
\hline Earnings & $\begin{array}{l}-0.480 \text { ** } \\
(0.015)\end{array}$ & $\begin{array}{l}-0.561^{* *} \\
(0.017)\end{array}$ & $\begin{array}{l}-0.493^{* *} \\
(0.020)\end{array}$ & $\begin{array}{l}-0.450 * * \\
(0.043)\end{array}$ & $\begin{array}{l}-0.401 * * \\
(0.050)\end{array}$ & $\begin{array}{l}-0.507^{* *} \\
(0.042)\end{array}$ \\
\hline R-Squared & 0.38 & 0.40 & 0.41 & 0.50 & 0.43 & 0.39 \\
\hline Wages & $\begin{array}{l}-0.348 * * \\
(0.015)\end{array}$ & $\begin{array}{l}-0.418 * * \\
(0.017)\end{array}$ & $\begin{array}{l}-0.384 * * \\
(0.020)\end{array}$ & $\begin{array}{l}-0.355^{* *} \\
(0.043)\end{array}$ & $\begin{array}{l}-0.262 * * \\
(0.052)\end{array}$ & $\begin{array}{l}-0.378 * * \\
(0.043)\end{array}$ \\
\hline R-Squared & 0.35 & 0.36 & 0.39 & 0.47 & 0.39 & 0.37 \\
\hline $\begin{array}{l}\text { Hours, conditional on } \\
\text { working }\end{array}$ & $\begin{array}{l}-0.132 \text { ** } \\
(0.008)\end{array}$ & $\begin{array}{l}-0.143 * * \\
(0.010)\end{array}$ & $\begin{array}{l}-0.109 * * \\
(0.010)\end{array}$ & $\begin{array}{l}-0.095 * * \\
(0.021)\end{array}$ & $\begin{array}{l}-0.139 * * \\
(0.024)\end{array}$ & $\begin{array}{l}-0.128 * * \\
(0.021)\end{array}$ \\
\hline R-Squared & 0.06 & 0.07 & 0.06 & 0.07 & 0.09 & 0.10 \\
\hline Sample Size & 8,145 & 6,866 & 4,463 & 908 & 776 & 1,026 \\
\hline $\begin{array}{l}\text { Notes: " denotes siginifica } \\
\text { unemployment to those jus } \\
\text { each city and year. } \\
\text { a Months in which inflation } \\
\text { bonths in which inflation } \\
{ }^{\mathrm{b}} \text { Months in which inflation } \\
{ }^{\mathrm{c}} \text { Month, 1991, and } 1994 \text { are }\end{array}$ & $\begin{array}{l}\text { level. Compar } \\
\text { unemployment } \\
\text { an } 6 \% \text { per mor } \\
\text { han } 20 \% \text { and } 20 \% \\
\text { h contain low, }\end{array}$ & $\begin{array}{l}\text { eond column o } \\
\text { rolling for educa } \\
\text { month. }\end{array}$ & $\begin{array}{l}\text { Te 4. Estimat } \\
\text { age, age squ }\end{array}$ & $\begin{array}{l}\text { e earnings anc } \\
\text { ale, dummies }\end{array}$ & $\begin{array}{l}\text { S of individual } \\
\text { h industry at t }\end{array}$ & $\begin{array}{l}\text { ving } \\
\text { id dummies for }\end{array}$ \\
\hline
\end{tabular}


Figure 1. Proportion of Males Employed in Manufacturing in Brazil's Major Metropolitan Areas, by Age, 1982-2002

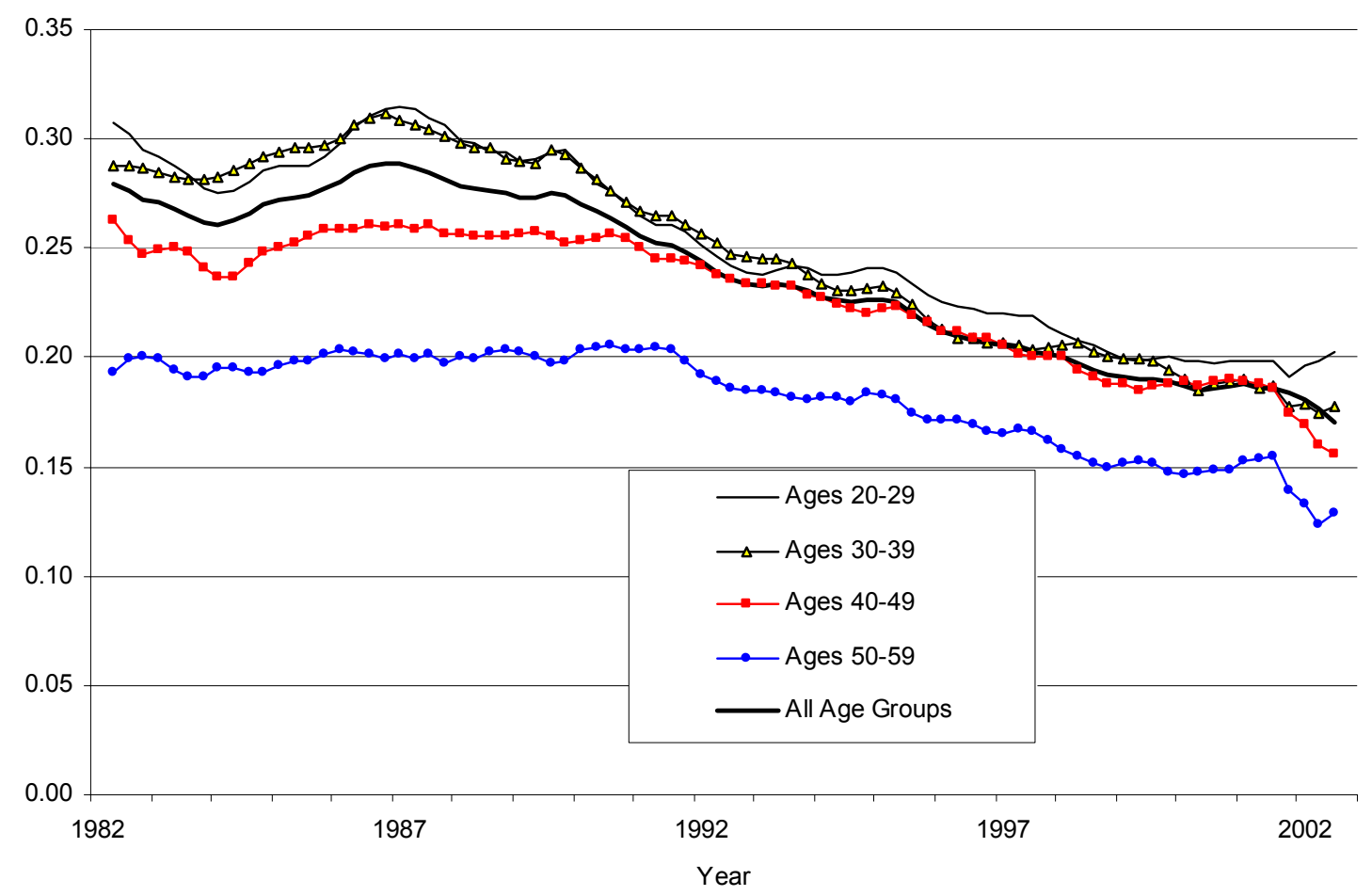

Figure 2. Proportion of Males Ages 20-59 Employed in Manufacturing, by Cohort, 1982-2002, Brazil

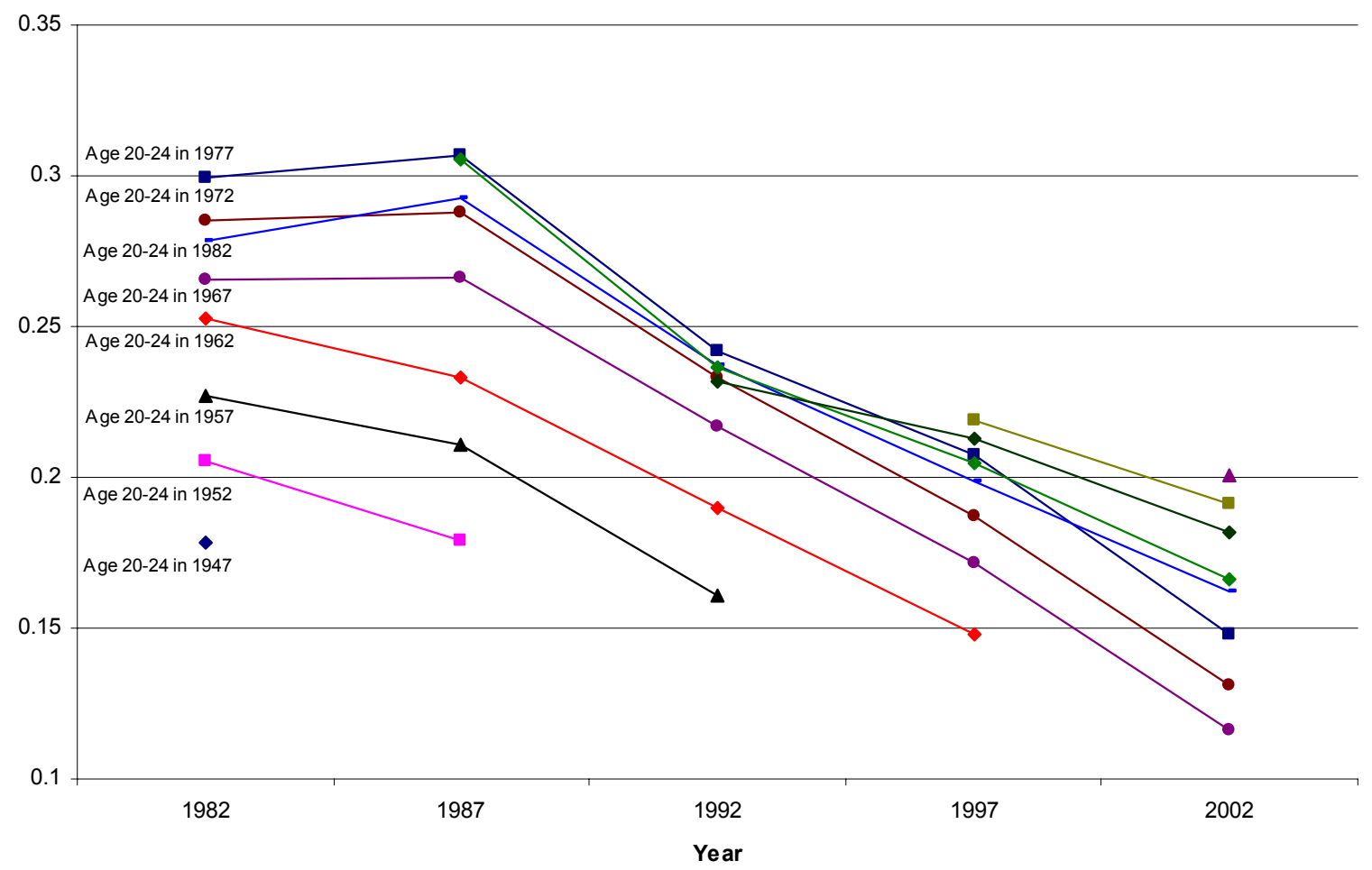


Figure 3. Monthly Entry Rates of Males into Manufacturing in Brazil's Major Metropolitan Areas, by Age, 1982-2002

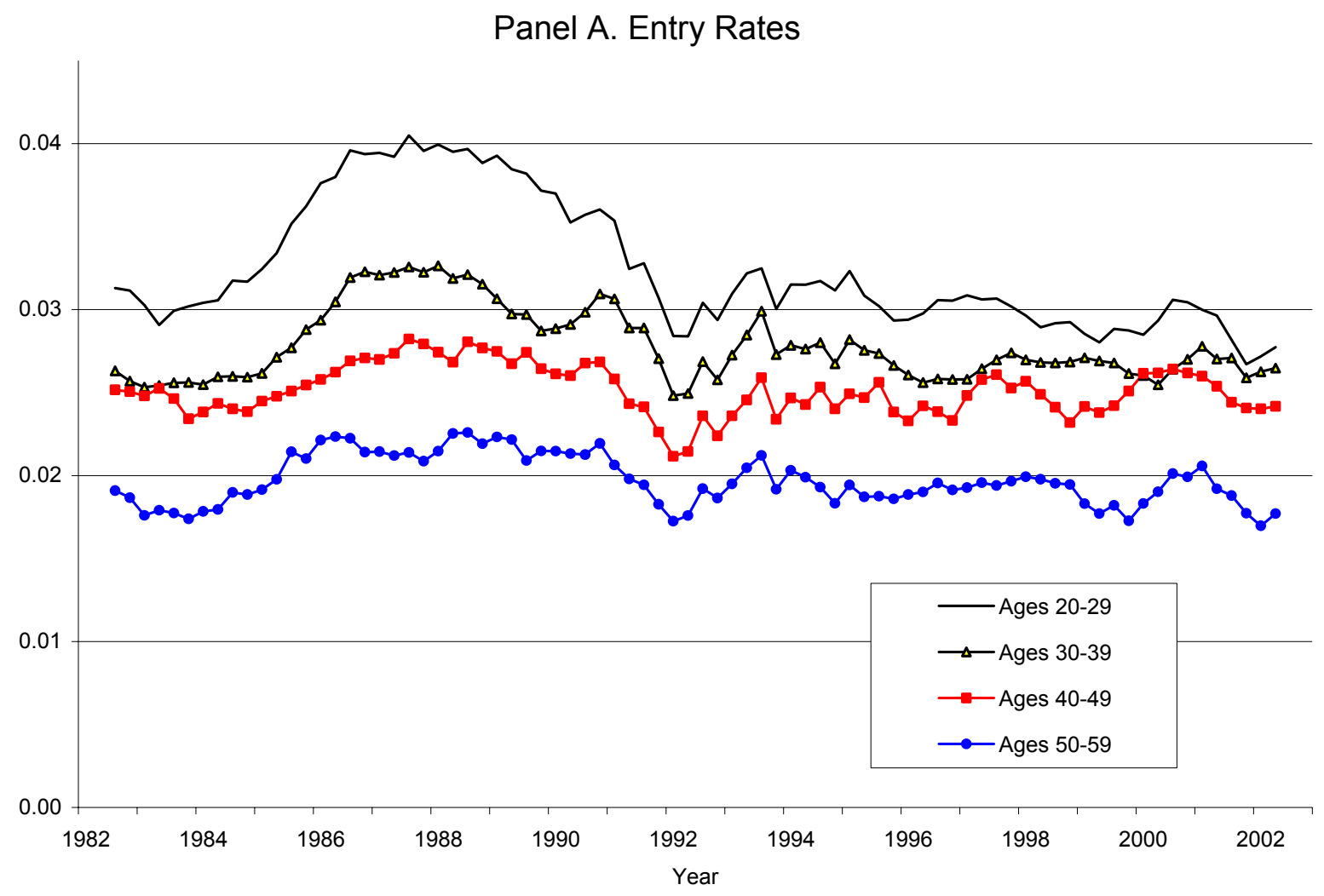

Panel B. Exit Rates

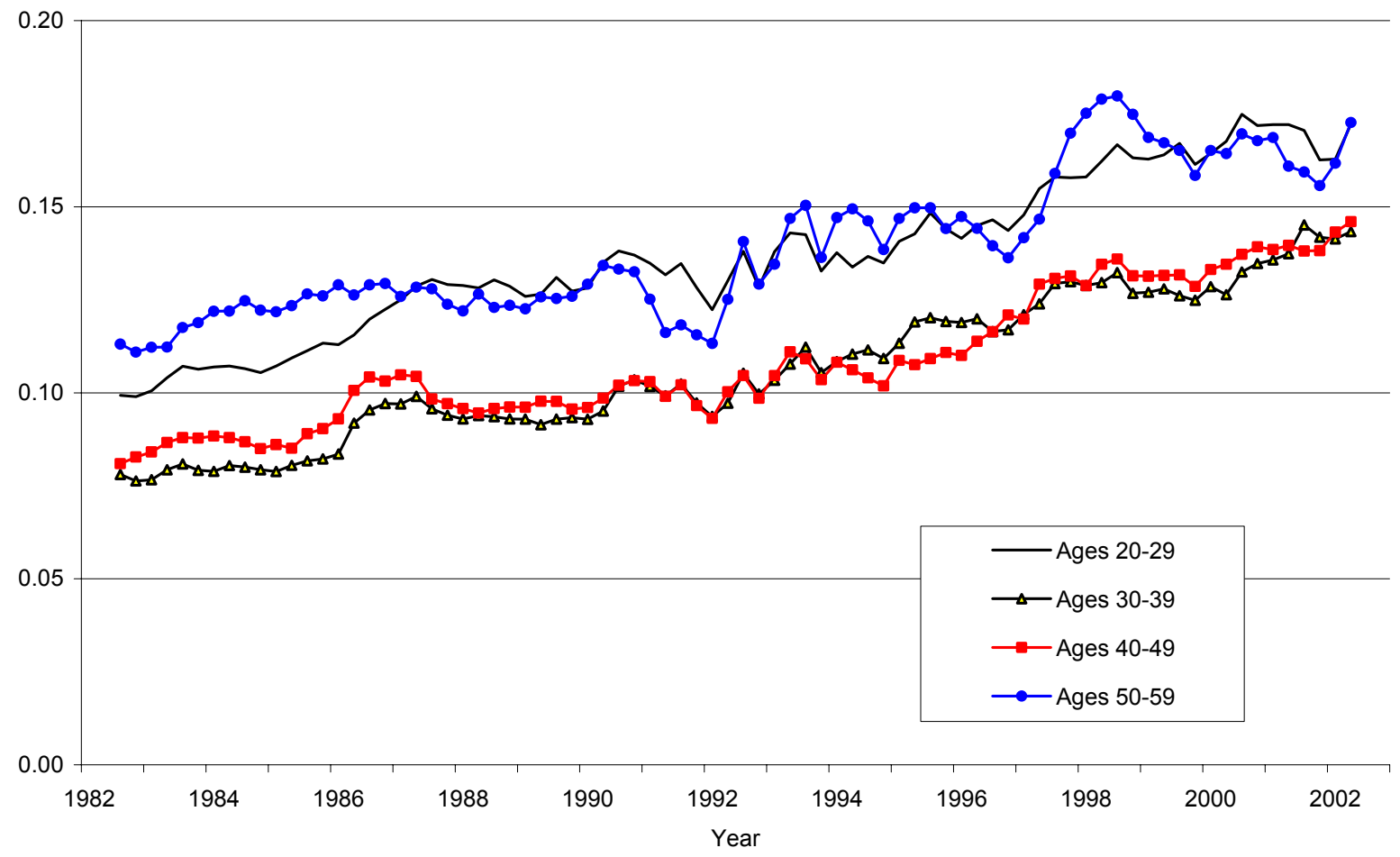


Figure 4. Mean Earnings and Wages of Non-Displaced, Pre-Displacement, and PostDisplacement Samples, by Propensity Score

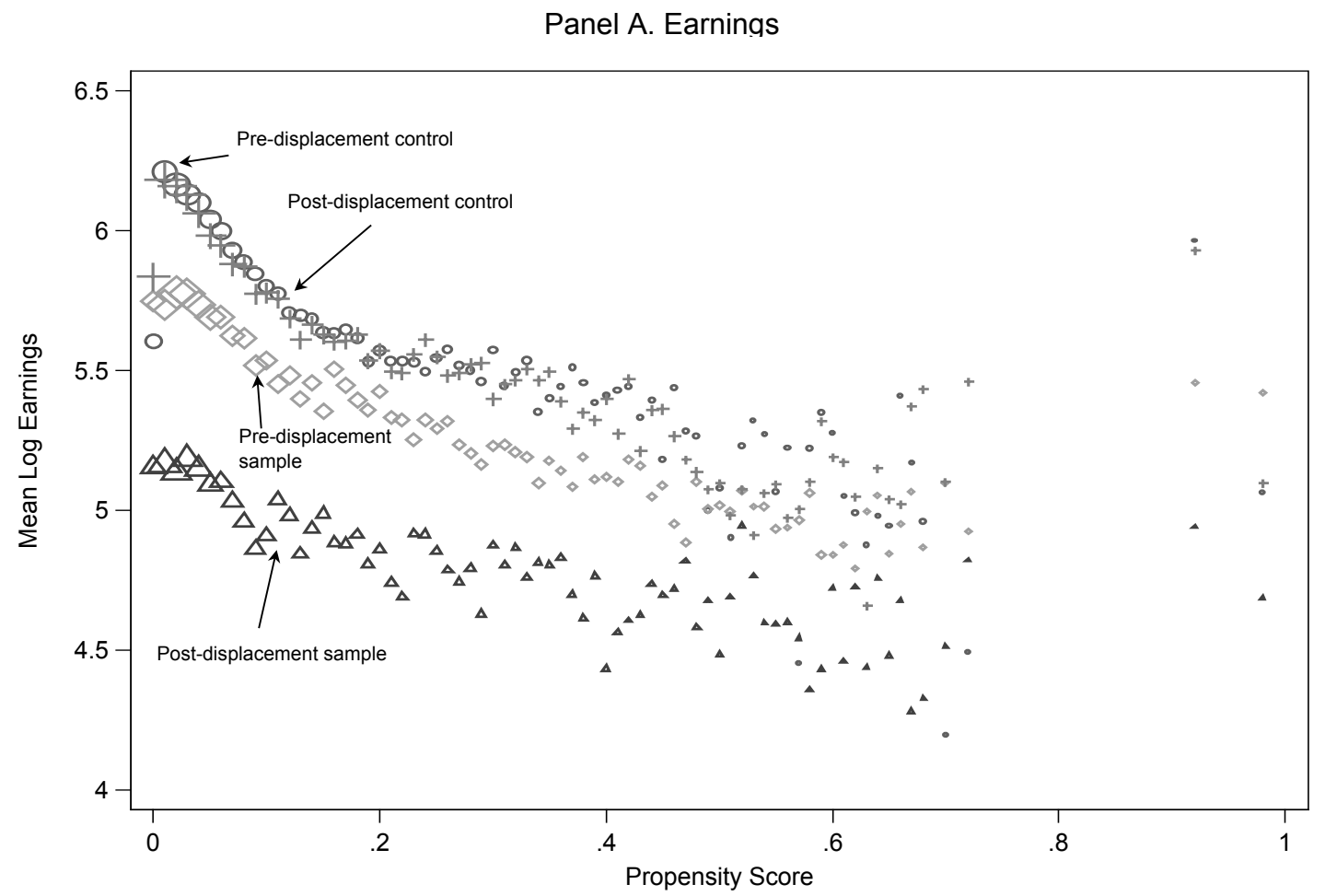

Panel B. Wages

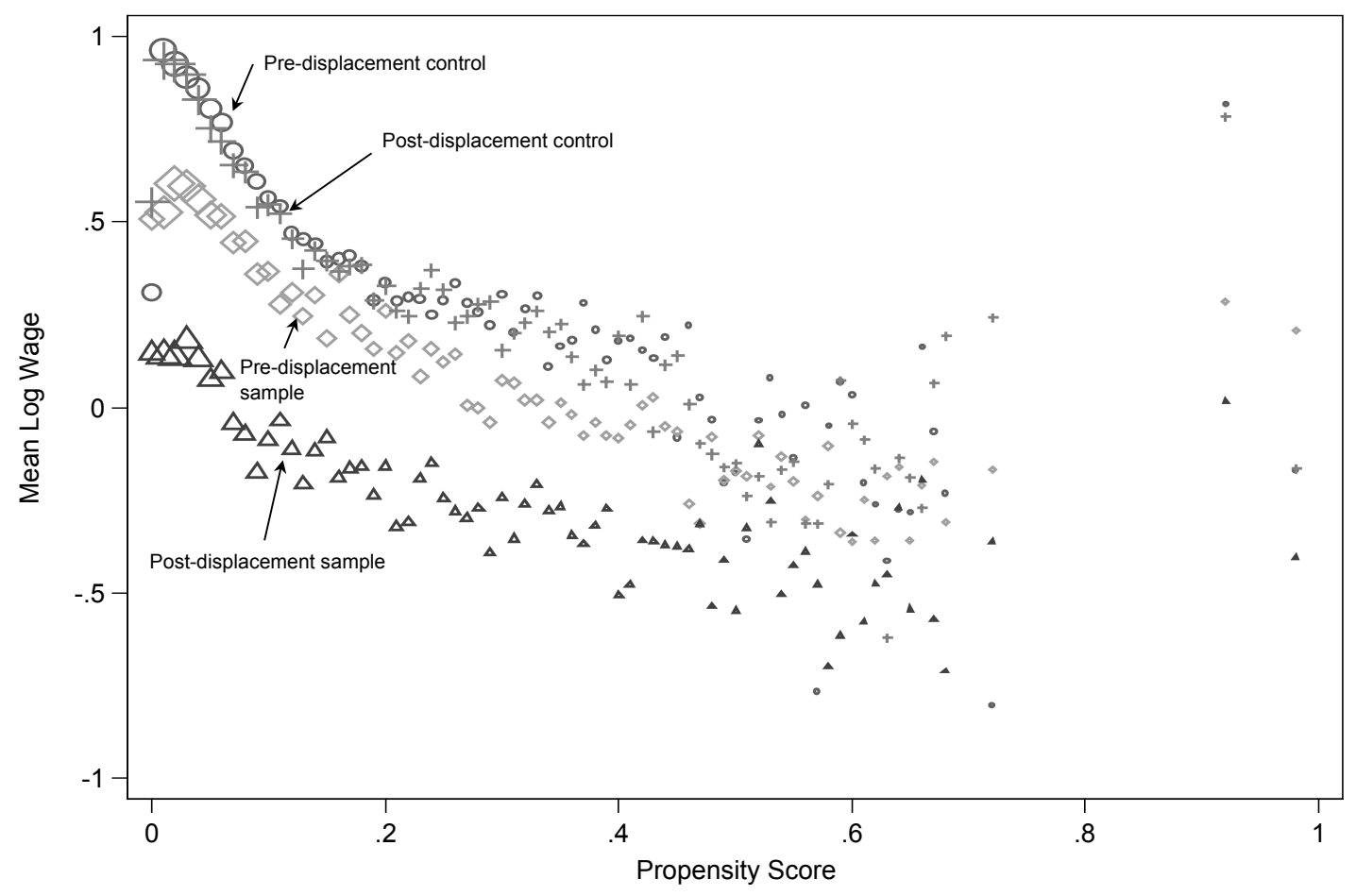


Figure 5. Effect of Displacement Through Unemployment on Log Earnings and Wages, by Age

1 year prior to impact, 1 month prior to impact, and 1 month prior to 1 -year after

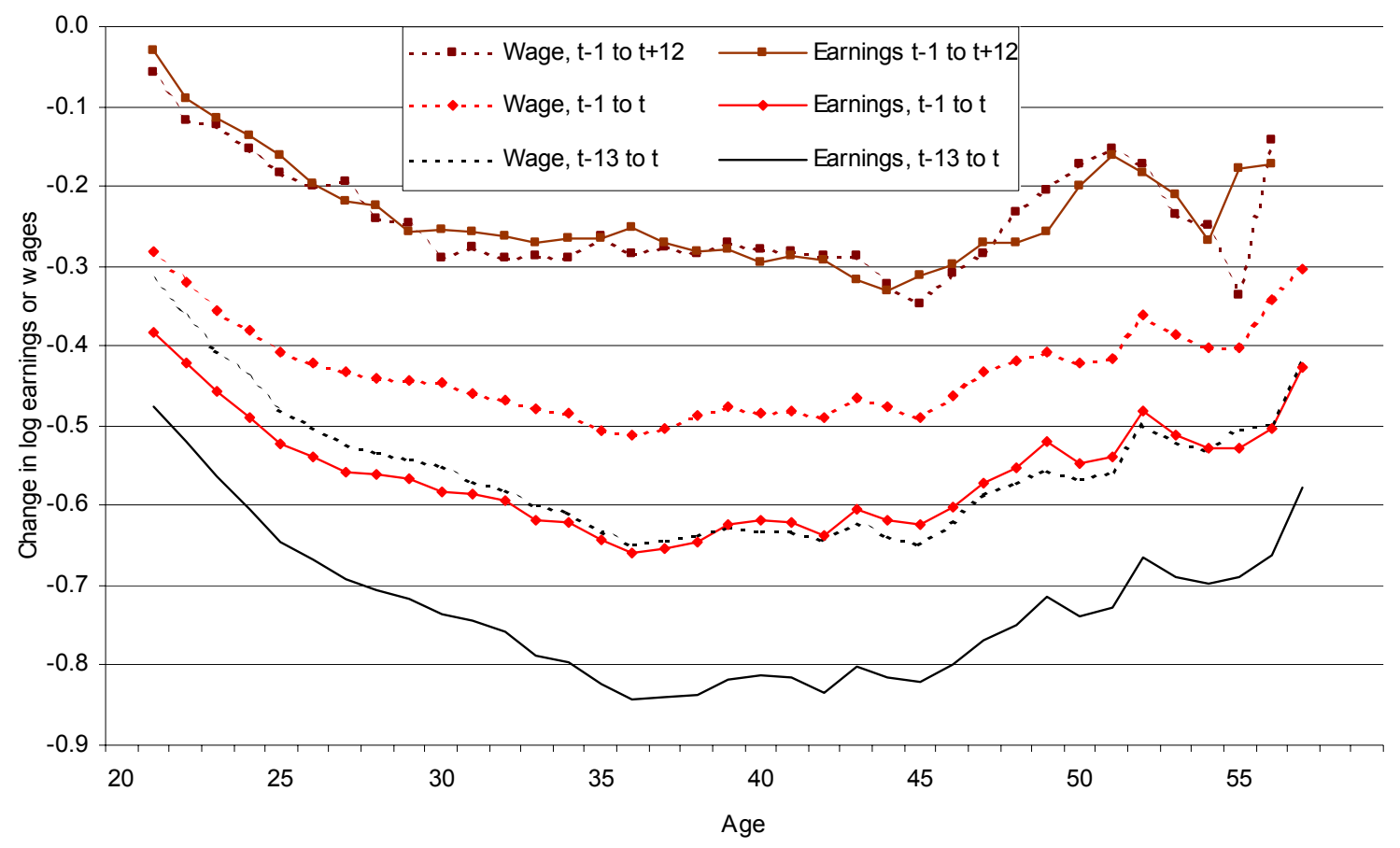


Figure 6. Impact Effect of Displacement on Wages, by Age and by Tenure

Manufacturing Workers Aged 20-59, Brazil, PME

Manu ifontu urina MNarkare Mnad on ao Rrazil DMAF

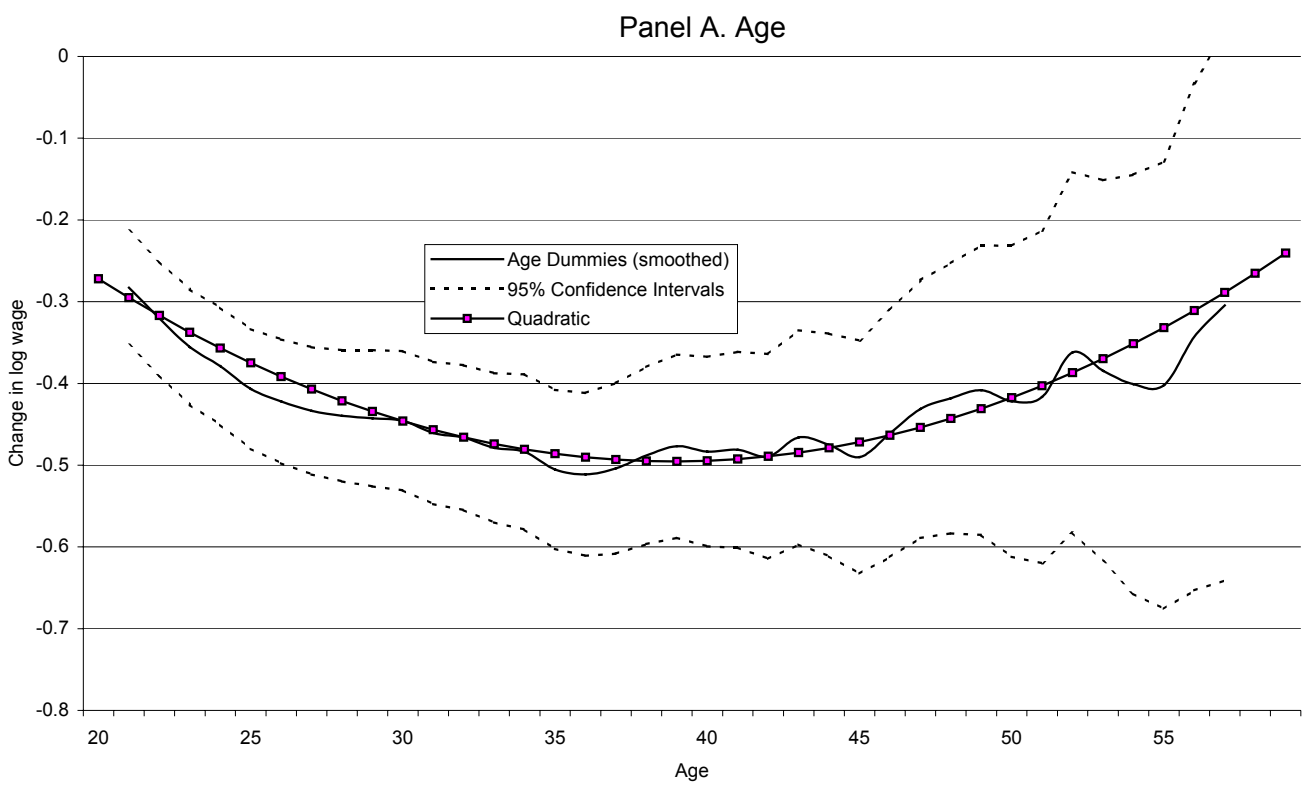

Panel B. Tenure

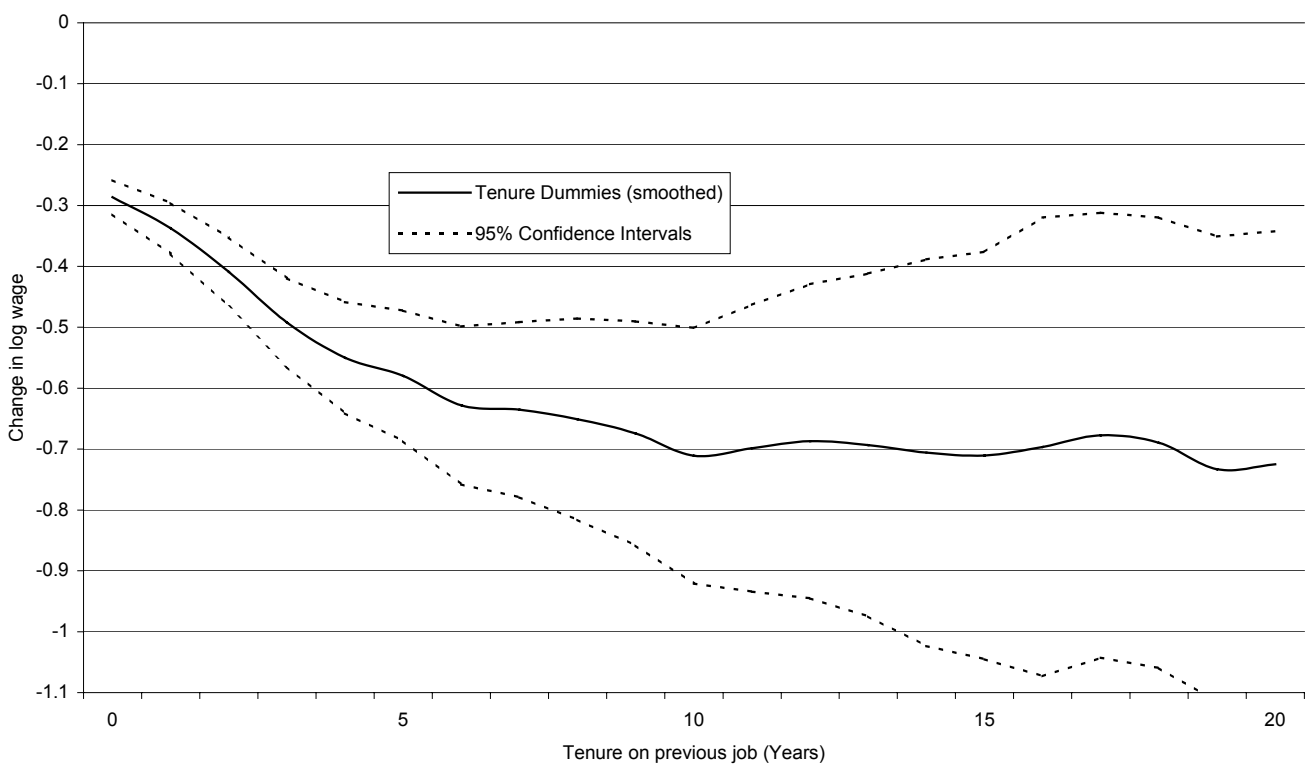


Figure 7. Average Tenure on Previous Job of Unemployed Workers, by Age

1982-2002, Brazil, PME

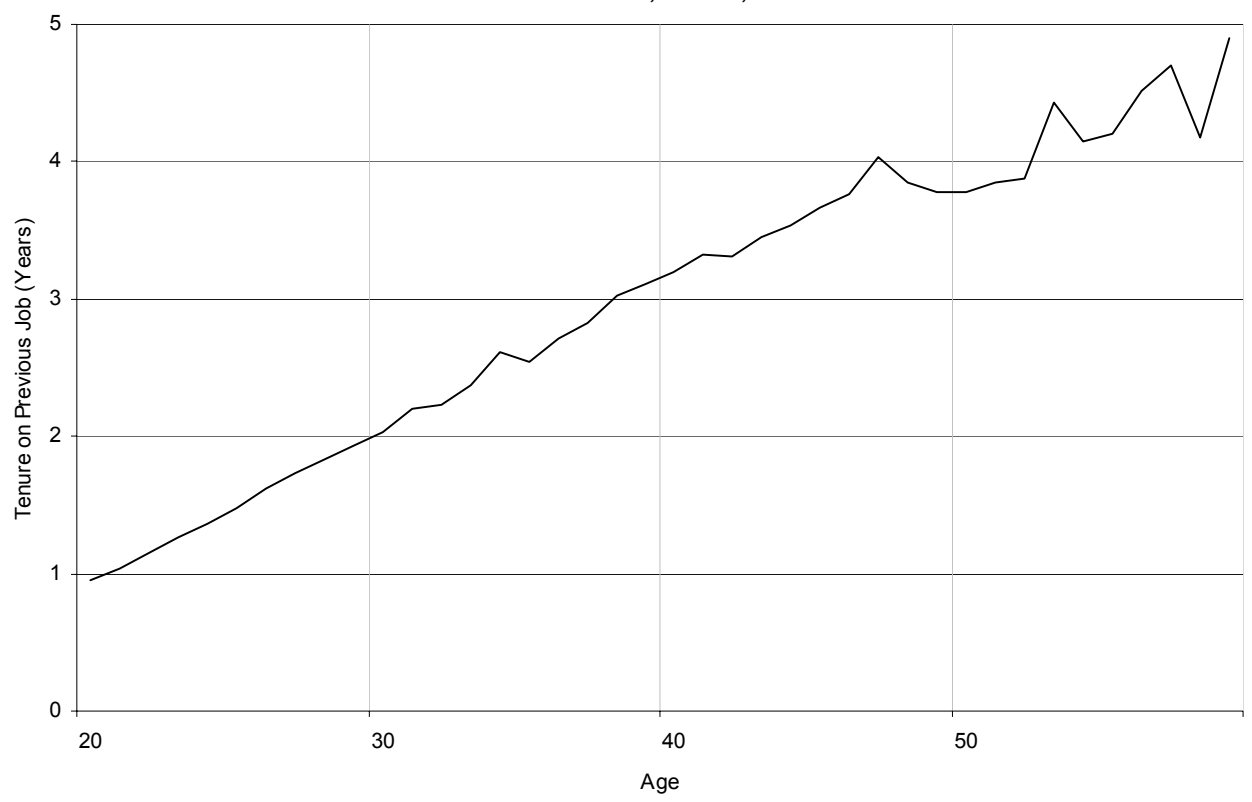

Figure 8. Tenure v. Age Effect on Displacement by Age

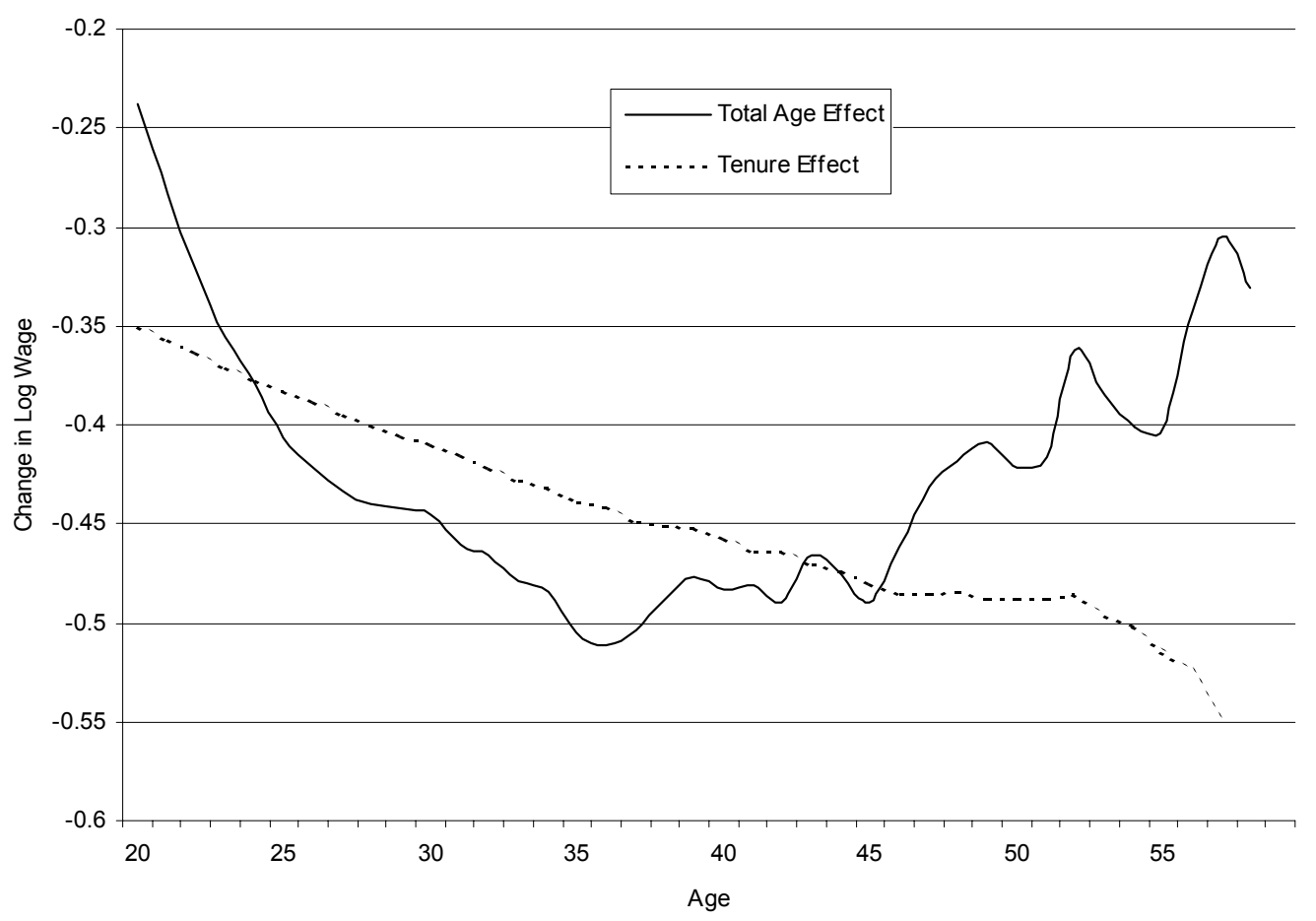

